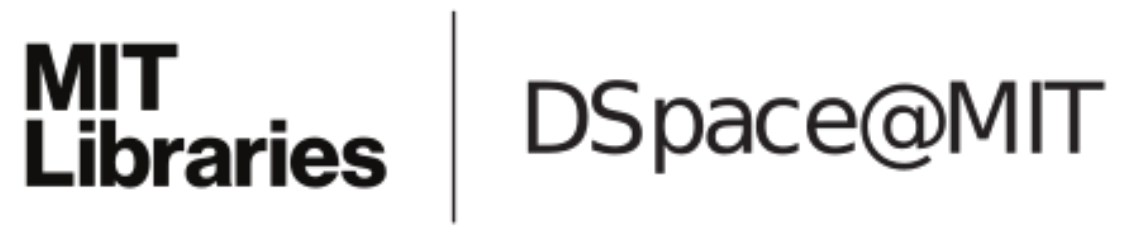

\author{
MIT Open Access Articles
}

\section{Electrocatalytic Activity Studies of Select Metal Surfaces and Implications in Li-Air Batteries}

The MIT Faculty has made this article openly available. Please share how this access benefits you. Your story matters.

Citation: Lu, Yi-Chun, Hubert A. Gasteiger, Ethan Crumlin, Robert McGuire, and Yang ShaoHorn. Electrocatalytic Activity Studies of Select Metal Surfaces and Implications in Li-Air Batteries. Journal of The Electrochemical Society 157, no. 9 (2010): A1016. (c) 2010 ECS - The Electrochemical Society

As Published: http://dx.doi.org/10.1149/1.3462981

Publisher: The Electrochemical Society

Persistent URL: http://hdl.handle.net/1721.1/79713

Version: Final published version: final published article, as it appeared in a journal, conference proceedings, or other formally published context

Terms of Use: Article is made available in accordance with the publisher's policy and may be subject to US copyright law. Please refer to the publisher's site for terms of use. 


\title{
Electrocatalytic Activity Studies of Select Metal Surfaces and Implications in Li-Air Batteries
}

\author{
Yi-Chun Lu, ${ }^{\text {a,d }}$ Hubert A. Gasteiger, ${ }^{\text {b,d,e,*,z }}$ Ethan Crumlin, \\ Robert McGuire, Jr., ${ }^{\mathrm{c}, \mathrm{d}}$ and Yang Shao-Horn ${ }^{\mathrm{a}, \mathrm{b}, \mathrm{d}, *, \mathrm{z}}$
}

${ }^{a}$ Department of Materials Science and Engineering, ${ }^{b}$ Department of Mechanical Engineering, ${ }^{c}$ Department of Chemistry, and dElectrochemical Energy Laboratory, Massachusetts Institute of Technology, Cambridge, Massachusetts 02139, USA

${ }^{e}$ Department of Chemistry, Technische Universität München, D-85747 Garching, Germany

\begin{abstract}
Rechargeable lithium-air batteries have the potential to provide $\approx 3$ times higher specific energy of fully packaged batteries than conventional lithium rechargeable batteries. However, very little is known about the oxygen reduction reaction (ORR) and oxygen evolution in the presence of lithium ions in aprotic electrolytes, which hinders the improvement of low round-trip efficiencies of current lithium-air batteries. We report the intrinsic ORR activity on glassy carbon (GC) as well as polycrystalline Au and Pt electrodes, where $\mathrm{Au}$ is the most active with an activity trend of $\mathrm{Au} \gg \mathrm{GC}>\mathrm{Pt}$. Rotating disk electrode (RDE) measurements were used to obtain the kinetic current of the ORR and the reaction order with respect to oxygen partial pressure in $1 \mathrm{M} \mathrm{LiClO}$ propylene carbonate:1,2-dimethoxyethane $(1: 2 \mathrm{v} / \mathrm{v})$. In addition, air electrodes with Vulcan carbon or Au or Pt nanoparticles supported on Vulcan were examined in $\mathrm{Li}-\mathrm{O}_{2}$ single cells, where the observed discharge cell voltages follow the catalytic trend established by RDE measurements. The ORR mechanism and the rate-determining steps were discussed and contrasted with the ORR activity trend in acid and alkaline solutions.

(C) 2010 The Electrochemical Society. [DOI: 10.1149/1.3462981] All rights reserved.
\end{abstract}

Manuscript submitted February 19, 2010; revised manuscript received May 6, 2010. Published July 21, 2010.

The specific energy of state-of-the-art rechargeable lithium-ion battery packs has reached $100-120 \mathrm{Wh} / \mathrm{kg}$ for electric vehicle applications $^{1,2}$ and further engineering optimization using currently known materials may yield up to $\approx 50 \%$ higher values $(\approx 180 \mathrm{Wh} /$ $\mathrm{kg})$. Unfortunately, this is still insufficient to support the long-term vision of sustainable transportation on the basis of full-range (300 miles) electric vehicles because the required $\approx 75 \mathrm{kWh}$ battery would weigh at least $\approx 400 \mathrm{~kg}$ and thus compromise vehicle efficiency. Therefore, further advances in specific energy are needed but are limited by low capacities of the lithium intercalation compounds used for the positive electrode. ${ }^{3,4}$ One promising approach, which could lead to at least a 4-fold higher specific energy of the positive electrode, involves replacing the intercalation compound with a catalytically active oxygen electrode, ${ }^{5}$ forming a so-called lithiumair (Li-air) battery. The discharge reaction in a Li-air battery is the reaction of oxygen with lithium ions to form lithium (per)oxide, regenerated during charge to lithium and oxygen: (i) $2 \mathrm{Li}$ $+\mathrm{O}_{2} \leftrightarrow \mathrm{Li}_{2} \mathrm{O}_{2}$ and (ii) $4 \mathrm{Li}+\mathrm{O}_{2} \leftrightarrow 2 \mathrm{Li}_{2} \mathrm{O}$. ${ }^{5}$ While the thermodynamic standard potential for $\mathrm{Li}_{2} \mathrm{O}_{2}$ formation is commonly quoted as $\approx 3.1 \mathrm{~V}$ vs Li $\left(\mathrm{V}_{\mathrm{Li}}\right),{ }^{5-7}$ no references to the thermodynamic database underlying its derivation were provided, and the value based on the NIST-JANAF thermochemical tables is actually $2.96 \mathrm{~V}_{\mathrm{Li}}{ }^{8,9}$ which may be compared to a very similar value of $2.91 \mathrm{~V}_{\mathrm{Li}}$ for $\mathrm{Li}_{2} \mathrm{O}$ formation. ${ }^{8}$ The latter values result in the expected positive entropy change for the thermal decomposition of lithium peroxide into gaseous oxygen and lithium oxide $\left(\mathrm{Li}_{2} \mathrm{O}_{2} \rightarrow \mathrm{Li}_{2} \mathrm{O}+0.5 \mathrm{O}_{2}\right)$, while the previously reported value of $\approx 3.1 \mathrm{~V}_{\mathrm{Li}}$ for $\mathrm{Li}_{2} \mathrm{O}_{2}$ would predict an obviously incorrect negative entropy change. Nevertheless, even though the formation of $\mathrm{Li}_{2} \mathrm{O}$ and $\mathrm{Li}_{2} \mathrm{O}_{2}$ are thermodynamically possible at nearly identical potentials, the actual product distribution is, of course, controlled by oxygen reduction reaction (ORR) kinetics, which can be influenced strongly by air electrode catalysts. Single-cell battery measurements followed by ex-situ Raman spectroscopy ${ }^{5,10}$ show $\mathrm{Li}_{2} \mathrm{O}_{2}$ as the major discharge product, while oxygen consumption data indicate the formation of both $\mathrm{Li}_{2} \mathrm{O}_{2}$ and $\mathrm{Li}_{2} \mathrm{O}$. ${ }^{11}$

Recent progress in Li-air battery research has yielded very high specific capacities, commonly referenced with respect to the mass of carbon in the electrode, ranging from 2500 to 5000

\footnotetext{
* Electrochemical Society Active Member.

${ }^{\text {z }}$ E-mail: hubert.gasteiger@mytum.de; shaohorn@mit.edu
}

$\mathrm{mAh} / \mathrm{g}_{\mathrm{C}}{ }^{7,10,12-14}$ for carbon-based air electrodes. ${ }^{5,7,10,12-17}$ However, to compare the specific capacities of Li-air cathodes with those of lithium intercalation compounds used in the positive electrodes of Li-ion batteries, ${ }^{4}$ it is appropriate to reference the specific capacities of lithium-air cathodes with respect to the weight of the discharged electrode (it is not appropriate to use the carbon weight only), i.e., to the weight of discharged lithium (per)oxide and carbon. ${ }^{18}$ For this case, the specific capacity of $\mathrm{Li}$-air cathodes is expected to reach roughly 900 to $1300 \mathrm{mAh} / \mathrm{g}_{\left(\mathrm{Li}_{x} \mathrm{O}_{2}+\mathrm{C}\right)}$, which is substantially larger than the specific capacities of current $\mathrm{Li}$-ion positive electrodes such as $\mathrm{LiCoO}_{2}$ presently with $160 \mathrm{mAh} / \mathrm{g}_{\mathrm{LiCoO}}$, as discussed previously. ${ }^{18}$ However, despite these successes, there are many key challenges that limit the practical use of this technology: (i) poor cycle life and (ii) high overpotentials on charge and discharge even at very low current densities $\left(0.01-0.5 \mathrm{~mA} / \mathrm{cm}_{\text {electrode }}^{2},\right)^{5,6,12,13}$ resulting in low round-trip efficiencies $(<60 \%)$ and low power capability. Particularly, the latter are expected to strongly depend on the catalytic activity of the electrodes, but little is known about the electrocatalytic reduction and evolution of oxygen in the presence of lithium ions in aprotic electrolytes, thus hindering the progress of rechargeable Li-air battery technology.

The effect of different catalyst materials on the Li-air battery performance has only been evaluated using carbon-based cathodes, ${ }^{5,10,15,17}$ for which it is difficult to deconvolute the activity of the catalyst from that of the carbon additive. In single-cell Li-air battery tests, oxygen reduction cathodes catalyzed by metals, ${ }^{15}$ metal complexes, ${ }^{5}$ and metal oxides ${ }^{10,15,17}$ have been examined, showing large differences in the discharge capacity among different catalysts ${ }^{10,15}$ but, surprisingly, nearly identical discharge voltages of $2.6 \mathrm{~V}_{\mathrm{Li}}{ }^{15}$ for dissimilar catalysts such as $\mathrm{Pt}, \mathrm{La}_{0.8} \mathrm{Sr}_{0.2} \mathrm{MnO}_{3}$, and oxides of $\mathrm{Fe}, \mathrm{Co}, \mathrm{Ni}, \mathrm{Cu}$, and $\mathrm{Mn}$. This could either be explained by assuming that the ORR kinetics in a Li-air cathode is not a catalytically sensitive reaction or, as indeed shown in this study, by assuming that the ORR kinetics is dominated by the high activity of the carbon additive used in these catalyst studies $(60-75 \mathrm{wt} \%$ carbon). ${ }^{10,15}$ Therefore, testing carbon-containing composite air electrodes in single-cell $\mathrm{Li}-\mathrm{O}_{2}$ batteries may not be successful in differentiating nor quantifying the intrinsic activity of different electrocatalysts, that is, the correlation between the reported discharge capacities/voltages and the catalytic activities of different catalysts is not necessarily straightforward because $(i)$ oxygen mass transport resistances are likely to affect cell voltage and impact electrode capacity due to the blocking effect of insoluble lithium (per)oxide 
formed during discharge inside the air electrode pores: ${ }^{11,19}$ (ii) the catalyst surfaces may be partially blocked by lithium (per)oxide discharge products; ${ }^{11}$ and (iii) the activity of cathodes containing catalyst powder and carbon can be influenced greatly by the ORR activity of carbon, as its mass fraction in these cathodes is large $\left(60-75\right.$ wt \% carbon $\left.{ }^{10,15,17}\right)$. Therefore, we have developed a rotating disk electrode (RDE) technique that enables a quantitative determination of the catalytic activity of various electrode materials in the absence of the above-described constraints. Thus, one can explore the fundamental parameters and mechanisms that govern the activity of $\mathrm{Li}$-air cathode catalysts for the ORR and the oxygen evolution reaction (OER), guiding the development of highly active air electrodes that are prerequisites for viable rechargeable $\mathrm{Li}$-air batteries.

In this study, we investigate the ORR activity on the surfaces of glassy carbon (GC) as well as polycrystalline Au and Pt electrodes by the RDE technique, which is widely used to measure the intrinsic electrocatalytic activity of fuel cell catalysts without interference from undefined oxygen mass transport resistances. ${ }^{20}$ In addition to quantifying the ORR activity on these three surfaces, we have examined the reaction order of the ORR with respect to oxygen partial pressure, $p_{\mathrm{O}_{2}}$, by using pure oxygen and dilute oxygen/argon mixtures. Moreover, we compare the discharge voltages of air electrodes made with Vulcan carbon as well as with $\mathrm{Au}$ or Pt nanoparticle catalyzed Vulcan carbon in single-cell $\mathrm{Li}-\mathrm{O}_{2}$ batteries, confirming that the observed discharge voltage in $\mathrm{Li}-\mathrm{O}_{2}$ single cells indeed follows the catalytic trend established by RDE measurements. Lastly, we discuss the possible reaction pathway and the ratedetermining steps of the ORR in $\mathrm{Li}^{+}$-containing aprotic electrolyte and further compare it to the ORR activity in an aqueous solution.

\section{Experimental}

All experiments were conducted at room temperature in $1 \mathrm{M}$ $\mathrm{LiClO}_{4}$ in propylene carbonate (PC):1,2-dimethoxyethane (DME) $(1: 2 \mathrm{v} / \mathrm{v})$ electrolyte. The solvent system was chosen because most Li-air battery data in the literature used either $\mathrm{PC}^{10,13-15,17}$ or PC with cosolvents. ${ }^{6,11,21,22}$ Electrolytes were prepared using lithium perchlorate $\left(\mathrm{LiClO}_{4}\right), \quad \mathrm{PC} \quad\left(<20 \mathrm{ppm} \mathrm{H}_{2} \mathrm{O}\right)$, and DME $\left(<30\right.$ ppm $\left.\mathrm{H}_{2} \mathrm{O}\right)$ acquired from Sigma-Aldrich.

$R D E$ measurements. - A three-electrode cell for RDE measurements containing $20 \mathrm{~mL}$ of the electrolyte was assembled in a dry argon-filled glove box to prevent moisture, oxygen, or nitrogen contamination. The gas lines to supply dry oxygen and argon were purged for $20 \mathrm{~min}$ before each experiment. The counter electrode was assembled by embedding Li foil into a nickel foam (INCOFOAM) support $\left(\approx 0.5 \mathrm{~cm}^{2}\right)$ with an attached nickel wire (Alfa Aesar, $99.995 \%$ ), which was sealed into a ground glass plug. The lithium-nickel foam assembly was wrapped in a Celgard 2350 battery separator material to prevent convective oxygen transport to the $\mathrm{Li}$ metal. The $\mathrm{Ag} / \mathrm{Ag}^{+}$reference electrode (nonaqueous $\mathrm{Ag} / \mathrm{Ag}^{+}$ electrode, BASi) consisted of a $\mathrm{Ag}$ wire immersed into $0.1 \mathrm{M}$ tetrabutylammonium hexafluorophosphate $\left(\mathrm{TBAPF}_{6}\right)$ (Sigma-Aldrich) and $0.01 \mathrm{M} \mathrm{AgNO}_{3}(\mathrm{BASi})$ in PC:DME $(1: 2 \mathrm{v} / \mathrm{v})$ solution and was connected to the main compartment by a Vycor frit. All potentials in this work, however, are referenced to the $\mathrm{Li} / \mathrm{Li}^{+}$potential, $\mathrm{V}_{\mathrm{Li}}$, obtained by calibration of the reference electrode against a fresh lithium wire before the experiments $\left(0 \mathrm{~V} \mathrm{vs} \mathrm{Li} / \mathrm{Li}^{+}\right.$corresponding to $-3.53 \pm 0.02 \mathrm{~V}$ vs $\left.\mathrm{Ag} / \mathrm{Ag}^{+}\right)$. The working electrodes were polished with $0.05 \mu \mathrm{m}$ alumina powder, rinsed in deionized water, dried in a vacuum oven, and then embedded into a Teflon RDE holder (Pine). The latter was attached to a rotating shaft and assembled into the cell by a plug with a ball-bearing seal. Once removed from the glove box, the cell was immediately purged with dry argon at sufficiently high flow rates $(\approx 0.1 \mathrm{slpm})$ to prevent the back-diffusion of air through the ball-bearing seal. The current density is referenced to the geometric disk electrode area $\left(0.196 \mathrm{~cm}^{2}\right)$ unless specified otherwise. Steady-state cyclic voltammograms $(\mathrm{CVs})$ were recorded between 2.0 and $4.4 \mathrm{~V}_{\mathrm{Li}}$ at a voltage sweep rate of 5 or $20 \mathrm{mV} / \mathrm{s}$. For ORR measurements, pure or Ar-diluted oxygen was bubbled through the cell at ambient pressure and CVs were recorded at various rotating speeds (100-900 rpm).

$\mathrm{Li}-\mathrm{O}_{2}$ cell measurements. - $\mathrm{A}$ Li- $\mathrm{O}_{2}$ testing cell was constructed with lithium metal as the negative electrode and the carbonbased air electrode as the positive electrode. The $\mathrm{Li}-\mathrm{O}_{2}$ cell configuration ${ }^{18}$ consists of a lithium foil $(15 \mathrm{~mm}$ in diameter), two pieces of Celgard separator (C480, $17 \mathrm{~mm}$ in diameter), and a Nafion-bonded air cathode (12.7 $\mathrm{mm}$ in diameter) coated onto Celgard C480 using either a pure Vulcan XC-72 carbon, 40 wt \% Au/C (Vulcan), or $40 \mathrm{wt} \% \mathrm{Pt} / \mathrm{C}$ (Vulcan) from Premetek. The impurity levels of all the catalysts used were examined by X-ray photoelectron spectroscopy (XPS, Kratos Axis Ultra spectrometer, monochromatized $\mathrm{Al} \mathrm{K} \alpha$ ). XPS results showed that only sulfur was detected, and the surface metal and chloride impurity levels of all the catalysts fell below the detection limit of XPS. The chemical analysis results from Premetek revealed that the total sulfur content in pure Vulcan is $<0.7 \mathrm{wt} \%$ and that in $\mathrm{Pt} / \mathrm{C}$ and $\mathrm{Au} / \mathrm{C}$ it is $<0.2 \mathrm{wt} \%$. High metal loading catalysts were used to ensure that the performance of cathodes with $\mathrm{Au} / \mathrm{C}$ and $\mathrm{Pt} / \mathrm{C}$ in $\mathrm{Li}-\mathrm{O}_{2}$ cells reflects differences in the intrinsic catalytic activity of $\mathrm{Au}$ and $\mathrm{Pt}$ relative to $\mathrm{C}$. Due to the high electronic conductivity of Vulcan carbon in the Nafion-bonded electrodes $(\approx 1 \mathrm{~S} / \mathrm{cm}),{ }^{23}$ electron conduction resistances in all cathodes are negligible. Metal dispersions of $\mathrm{Au} / \mathrm{C}$ and $\mathrm{Pt} / \mathrm{C}$ catalysts were estimated from $\mathrm{X}$-ray powder diffraction line broadening, yielding $\approx 13 \mathrm{~m}^{2} / \mathrm{g}_{\mathrm{Au}}$ and $\approx 80 \mathrm{~m}^{2} / \mathrm{g}_{\mathrm{Pt}}$, respectively. Cathodes with a Nafion/carbon weight ratio of $0.5 / 1$ were prepared by coating ultrasonicated inks composed of carbon or catalyst, a Nafion dispersion (DE2020, Ion Power), and 2-propanol (Sigma-Aldrich) onto the separator. After air drying at $20^{\circ} \mathrm{C}$ for about $20 \mathrm{~min}$ and subsequently vacuum drying for $3 \mathrm{~h}$, the cathodes were weighed and then each cathode was soaked in fresh $10 \mathrm{~mL}$ electrolyte. Considering that the total amount of protons in each electrode (ca. $0.4 \mu \mathrm{mol}_{\mathrm{H}^{+}}$, based on a maximum of $0.8 \mathrm{mg}_{\mathrm{C}}$, a Nafion/carbon weight ratio of $0.5 / 1$, and a Nafion equivalent weight of $\left.\approx 1000 \mathrm{~g}_{\mathrm{Nafion}} / \mathrm{mol}_{\mathrm{H}^{+}}\right)$is $10^{4}$ times less than the total amount of lithium ions $\left(0.01 \mathrm{~mol}_{\mathrm{Li}^{+}}\right)$, the protons contained in Nafion are quantitatively ion-exchanged by $\mathrm{Li}^{+}$, as shown, e.g., by Okada. ${ }^{24}$ All cathode carbon loadings were within $0.65 \pm 0.15 \mathrm{mg}\left(0.51 \pm 0.12 \mathrm{mg} / \mathrm{cm}_{\text {electrode }}^{2}\right) . \mathrm{Li}-\mathrm{O}_{2}$ cells were assembled in the following order: (i) placing a lithium foil onto the cell's stainless steel current collector, (ii) adding $10 \mu \mathrm{L}$ of electrolyte, (iii) placing two pieces of the separator onto the lithium foil, (iv) adding $10 \mu \mathrm{L}$ of electrolyte, $(v)$ placing the cathode-coated separator onto the separator, (vi) adding on top a cathode current collector (17 mm diameter 316 stainless steel mesh pushed against the electrode by a 316 stainless steel spring), and (vii) purging the cell with PC/DME-saturated oxygen for $10 \mathrm{~min}$. Afterward, the cells were sealed and tested galvanostatically (Solartron 1470) at $0.1 \mathrm{~mA} / \mathrm{cm}_{\text {electrode }}^{2}$ with a low voltage limit of $2.0 \mathrm{~V}_{\mathrm{Li}}$ and upper limits of $4.5 \mathrm{~V}_{\mathrm{Li}}$ (pure carbon, subsequently held at $4.5 \mathrm{~V}_{\mathrm{Li}}$ for $5 \mathrm{~h}$ before the next discharge), $4.4 \mathrm{~V}_{\mathrm{Li}}\left(\mathrm{Au} / \mathrm{C}\right.$, no holding), and $4.0 \mathrm{~V}_{\mathrm{Li}}$ (Pt/C, no holding) to avoid electrolyte decomposition.

\section{Results}

ORR kinetics on well-defined GC electrodes.-Figure 1a shows the steady-state $\mathrm{CV}$ of a GC electrode for $1 \mathrm{M} \mathrm{LiClO}_{4}$ in PC:DME $(1: 2 \mathrm{v} / \mathrm{v})$ both in the absence (argon purged) and presence of oxygen (oxygen purged) at a rotation rate of $100 \mathrm{rpm}$ (blue solid line) and a scan rate of $5 \mathrm{mV} / \mathrm{s}$. As expected, no significant anodic or cathodic current was observed in the background CV in Ar, which suggests that the electrolyte used in this system is relatively stable from 2.0 to $4.4 \mathrm{~V}_{\mathrm{Li}}$. In $100 \% \mathrm{O}_{2}$, the onset of the reduction current on GC occurs below $\approx 2.8 \mathrm{~V}_{\mathrm{Li}}$, which was unchanged with $\left(1 \mathrm{M} \mathrm{LiClO}_{4}\right.$ in PC:DME having 1:2 v/v) and without PC (1 $\mathrm{M} \mathrm{LiClO}_{4}$ in DME) in the electrolyte.

We show that the observed reduction current in Fig. 1a is indeed due to reactions with dissolved oxygen in the electrolyte by exam- 


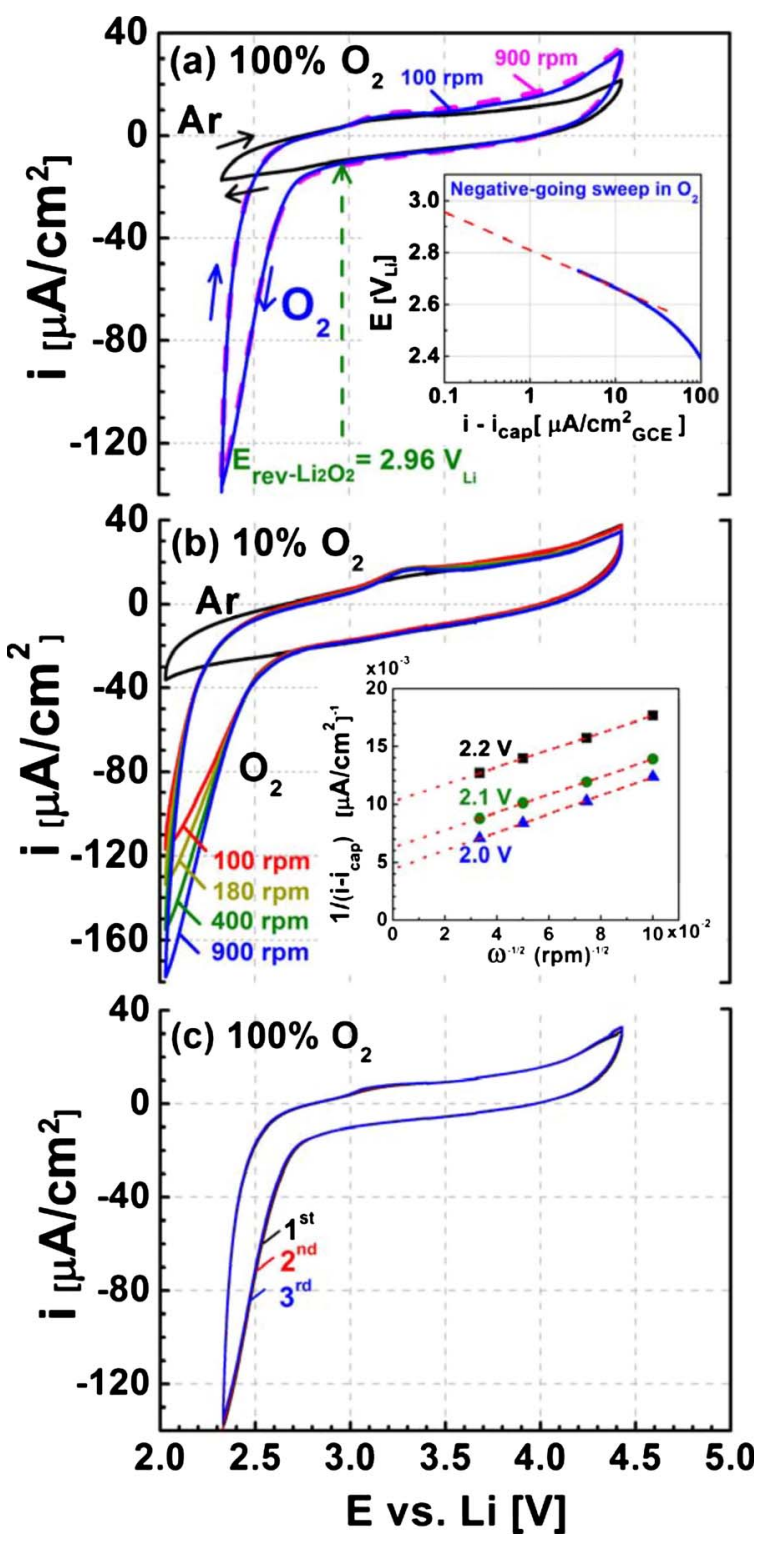

Figure 1. (Color online) (a) CVs of a GC electrode in $1 \mathrm{M} \mathrm{LiClO}_{4} \mathrm{PC}: \mathrm{DME}$ $(1: 2 \mathrm{v} / \mathrm{v})$ at $5 \mathrm{mV} / \mathrm{s}$ saturated with either Ar at $100 \mathrm{rpm}$ (black line) or $\mathrm{O}_{2}$ at both $100 \mathrm{rpm}$ (blue solid line) or $900 \mathrm{rpm}$ (pink dotted line). The inset shows the net ORR current density for the negative-going sweep, which was obtained by up-shifting the reduction current in $\mathrm{O}_{2}$ by $0.9 \mu \mathrm{A} / \mathrm{cm}^{2}$ so that the net current density for the ORR after the capacitive correction (i.e., $i-i_{\text {cap }}$ ) is zero at the equilibrium potential of $2.96 \mathrm{~V}_{\mathrm{Li}}$; the red dashed line is a guide to the eye to estimate the potential at lower current densities. (b) CVs of a GC electrode in $1 \mathrm{M} \mathrm{LiClO}_{4} \mathrm{PC}: \mathrm{DME}(1: 2 \mathrm{v} / \mathrm{v})$ in $\mathrm{Ar}$ and $10 \% \mathrm{O}_{2}$ at $20 \mathrm{mV} / \mathrm{s}$ collected at 100, 180, 400, and $900 \mathrm{rpm}$. Inset: Levich-Koutecky plot of the capacitive-corrected net ORR currents $\left(i-i_{\text {cap }}\right)$ at $2.2,2.1$, and $2.0 \mathrm{~V}_{\mathrm{Li}}$ with slopes of $77 \pm 3 \mathrm{~cm}^{2} \mathrm{rpm}^{0.5} / \mathrm{mA}$ (corresponding to $8.1 \pm 0.3 \mathrm{~cm}^{2} \mathrm{~s}^{0.5} / \mathrm{mA}$ ). (c) Reproducibility of subsequent voltammetric scans illustrated by the first (black line), second (red line), and third (blue line) scans.

ining the rotation rate dependence of reduction current with $100 \%$ (Fig. 1a) and $10 \% \mathrm{O}_{2}$ (Fig. 1b). Unfortunately, no difference in the ORR current was observed between $100 \mathrm{rpm}$ (blue solid line) and $900 \mathrm{rpm}$ (pink dotted line) in $100 \% \mathrm{O}_{2}$ (Fig. 1a). This could be explained if the diffusion-limited current density $\left(i_{\mathrm{d}}\right)$ were much larger than the kinetic current density $\left(i_{\mathrm{k}}\right)$. The former can be obtained from the Levich equation

$$
i_{\mathrm{d}}=0.62 n F D_{\mathrm{O}}^{2 / 3} v^{-1 / 6} C_{\mathrm{O}}^{*} \omega^{1 / 2}
$$

where $n$ is the overall number of transferred electrons, $F$ is the Faraday constant $(96,485 \mathrm{~A} \mathrm{~s} / \mathrm{mol}), D_{\mathrm{O}}$ is the diffusion coefficient of $\mathrm{O}_{2}, \omega$ is the rotation rate (in $\mathrm{rad} / \mathrm{s}$ ), $v$ is the kinematic viscosity of the solution, and $C_{\mathrm{O}}^{*}$ is the saturated $\mathrm{O}_{2}$ concentration in the electrolyte. Because $D_{\mathrm{O}}, v$, and $C_{\mathrm{O}}^{*}$ in PC:DME $(1: 2 \mathrm{v} / \mathrm{v})$ with $1 \mathrm{M}$ $\mathrm{LiClO}_{4}$ are not expected to be significantly different from that with $1 \mathrm{M} \mathrm{LiPF}_{6}$, their values can be estimated from those provided by Read et al. ${ }^{21}$ The estimated oxygen solubility for PC:DME $(1: 2 \mathrm{v} / \mathrm{v})$ is $C_{\mathrm{O}}^{*}=4.46 \times 10^{-6} \mathrm{~mol} / \mathrm{cm}^{3}$ with a dynamic viscosity of $\eta$ $=1.98 \times 10^{-2} \mathrm{~Pa} / \mathrm{s}$ equivalent to $v=0.02 \mathrm{~cm}^{2} / \mathrm{s}$ for an average density of $0.98 \mathrm{~g} / \mathrm{cm}^{3}$. In $1 \mathrm{M} \mathrm{LiPF}_{6}$ PC:DME $(1: 1 \mathrm{v} / \mathrm{v}), D_{\mathrm{O}}$ and $\eta$ were given as $7.0 \times 10^{-6} \mathrm{~cm}^{2} / \mathrm{s}$ and $2.59 \times 10^{-2} \mathrm{~Pa} / \mathrm{s},{ }^{21}$ which by the Stokes-Einstein relation yields an estimated value of $D_{\mathrm{O}}$ $=9.2 \times 10^{-6} \mathrm{~cm}^{2} / \mathrm{s}$ for PC:DME $(1: 2 \mathrm{v} / \mathrm{v})$. Using these values in Eq. 1, one can estimate the values of the minimum diffusion-limited current densities (i.e., that for the one-electron reduction to $\mathrm{LiO}_{2}$ ) equating to $\approx 750$ and $\approx 2200 \mu \mathrm{A} / \mathrm{cm}^{2}$ at 100 and $900 \mathrm{rpm}$, respectively. These diffusion-limited current densities are more than 5 -fold larger than the measured current densities $\left(\approx 140 \mu \mathrm{A} / \mathrm{cm}^{2}\right.$, see Fig. 1a), which explains the lack of rotation rate dependence and indicates that the ORR current density is essentially kinetically limited with $100 \% \mathrm{O}_{2}$. We then performed RDE measurements with $10 \%$ $\mathrm{O}_{2}$ balanced with Ar (Fig. 1b), which lowers the diffusion-limiting current density by a factor of 10 compared to $100 \% \mathrm{O}_{2}$ due to the 10 -fold lower oxygen concentration following Henry's law. A clear rotation rate dependence of the ORR currents below $\approx 2.3 \mathrm{~V}_{\mathrm{Li}}$ was noted in the steady-state CVs on GC with $10 \% \mathrm{O}_{2} / \mathrm{Ar}$ in Fig. 1 , which confirmed that the observed reduction currents involved dissolved oxygen. The reduction current for $10 \% \mathrm{O}_{2}$ had a lower onset potential of $\approx 2.6 \mathrm{~V}_{\mathrm{Li}}$ compared to $\approx 2.8 \mathrm{~V}_{\mathrm{Li}}$ for $100 \% \mathrm{O}_{2}$, the cause of which will be discussed in detail later. A linear relationship (the Levich-Koutecky analysis) was found between RDE current and $\omega^{-1 / 2}$ at constant-potential lines (Fig. 1b inset), with a slope value of $8.1 \pm 0.3 \mathrm{~cm}^{2} \mathrm{~s}^{0.5} / \mathrm{mA}$. In principle, the slope can be used to determine the number of electrons such as $n=1$ for $\mathrm{LiO}_{2}, n$ $=2$ for $\mathrm{Li}_{2} \mathrm{O}_{2}$, and $n=4$ for $\mathrm{Li}_{2} \mathrm{O}$ transferred in the rate-limiting step using the following relationship

$$
\text { slope }=\left(0.62 n F D_{\mathrm{O}}^{2 / 3} v^{-1 / 6} C_{\mathrm{O}}^{*}\right)^{-1}
$$

provided that precise values of $D_{\mathrm{O}}, v$, and $C_{\mathrm{O}}^{*}$ were available. Unfortunately, the values of $D_{\mathrm{O}}, v$, and $C_{\mathrm{O}}^{*}$ are only reported in a similar electrolyte [i.e., $1 \mathrm{M} \mathrm{LiPF}_{6}$ in PC:DME $(1: 1 \mathrm{v} / \mathrm{v})^{21}$ ] but are not available for $1 \mathrm{M} \mathrm{LiClO}_{4}$ in PC:DME $(1: 2 \mathrm{v} / \mathrm{v})$ used in our study. Therefore, it is not possible to extract the accurate number of electron transfer from the RDE data in this work.

Quantifying intrinsic ORR activity of GC electrodes and implications in $\mathrm{Li}-\mathrm{O}_{2}$ cells. - The net ORR kinetic current density (after capacitive correction) is shown as a function of voltage in the inset of Fig. 1a. The maximum IR correction is only $\approx 2 \mathrm{mV}$ (the highest total current is $\approx 30 \mu \mathrm{A}$; the measured resistivity of the system is $\approx 60 \Omega$ ), so that no ohmic potential drop corrections were applied here. The ORR kinetic current density at $2.7 \mathrm{~V}_{\mathrm{Li}}$ is $\approx 4 \mu \mathrm{A} / \mathrm{cm}_{\mathrm{GCE}}^{2}$, which is much higher (by 20 times) than the $\approx 0.2 \mu \mathrm{A} / \mathrm{cm}_{\mathrm{C}}^{2}$ extracted from currents used in previous studies based on $70 \mathrm{~mA} / \mathrm{g}_{\mathrm{C}}$ and a carbon Brunauer-Emmet-Teller area of $\approx 40 \mathrm{~m}^{2} / \mathrm{g}_{\mathrm{C}}$. $10,15,19$ This result indicates that the intrinsic activity of carbon itself is high enough to explain the discharge voltage plateaus observed in previous studies on carbon-based electrodes with or without an additional catalyst. ${ }^{5,10,12,13,15-17}$ Therefore, the catalyst-independent discharge voltages $\left(\approx 2.6 \mathrm{~V}_{\mathrm{Li}}\right)^{15}$ reported for $\mathrm{Li}$-air cathodes with different catalysts mixed with Super S carbon $(60-75 \text { wt } \% \text { carbon })^{15}$ are likely to result from the high activity of carbon.

However, even though similar discharge voltages were reported for all the different catalysts added to the carbon-based Li-air cathodes in the work by Débart et al., ${ }^{15}$ large differences were observed 
with regard to capacity and capacity retention. As shown previously ${ }^{6}$ capacity can be reduced significantly with decreasing cathode void volume, which is available for lithium (per)oxide formation. Therefore, for a rigorous comparison, electrodes with different catalysts would have to have identical void volumes, as was done in a recent study on various catalysts for Li-air cathodes. ${ }^{18}$ Unfortunately, no information was provided by Débart et al. ${ }^{15}$ regarding the morphologies of the different catalysts used (particle size, particle shape, and catalyst surface area). It is, therefore, not possible to determine whether differences in cathode void volume may have caused the observed differences in capacity between the differently catalyzed cathodes. Therefore, as far as ORR activity is concerned, capacity and capacity retention of electrodes with potentially very different electrodes are not meaningful descriptors. It is hypothesized here that the observed differences in capacity retention may be related to differences in lithium (per)oxide decomposition (OER) activities of the various catalysts on charge, where large differences in OER activity for Vulcan, $\mathrm{Pt} / \mathrm{C}$, and $\mathrm{Au} / \mathrm{C}$ catalysts were shown in our recent work. ${ }^{18}$

Consequently, ORR activity tests solely using carbon-based electrodes are not ideal to examine the intrinsic activity of different ORR cathode catalysts due to the interference from carbon support and/or carbon additives, an artifact avoided by the RDE technique shown in this study, which enables a more straightforward evaluation of the ORR activity. However, while the specific activity (i.e., the surface area normalized activity) of high surface area carbons used in Li-air cathodes should be reasonably similar to that of a GC electrode yet not identical, a quantitative comparison requires further measurements of the ORR activity of high surface area carbons in an RDE configuration as was developed for fuel cell catalysts, ${ }^{25}$ which is currently being tested in our laboratory.

Proposed soluble and insoluble ORR products on GC electrodes.-We discuss here the dissolution of ORR product(s) based on the imbalance between reduction and oxidation coulombic charges. Although the onset of an oxidation current at $\approx 3.6 \mathrm{~V}_{\mathrm{Li}}$ on $\mathrm{GC}$ in the positive-going scan of Fig. 1a agrees with charging curves of Li-air batteries with carbon electrodes, which show a charging voltage plateau starting from $\approx 3.9^{5}$ to $\approx 4.5 \mathrm{~V}_{\mathrm{Li}}$, ${ }^{15}$ the coulombic charge upon oxidation is only $\approx 10 \%$ of the preceding oxygen reduction charge. As there was no difference between the first negative-going scan of a fresh electrode and all subsequent cycles (Fig. 1c), the accumulation of surface insoluble ORR products upon cycles can be excluded, which poisons $\mathrm{Au}$ and Pt surfaces for $\mathrm{ORR}^{26,27}$ (i.e., no ORR currents in the second negative-going scan). Therefore, a significant fraction of ORR products (e.g., $\mathrm{Li}_{2} \mathrm{O}_{2}, \mathrm{Li}_{2} \mathrm{O}$, or $\mathrm{LiO}_{2}$ ) formed below $\approx 3 \mathrm{~V}_{\mathrm{Li}}$ dissolves into the electrolyte (20 $\mathrm{mL}$ ) in our RDE measurements (much less dissolution of ORR products is expected in $\mathrm{Li}-\mathrm{O}_{2}$ cells as the ratio of electrolyte volume to electrode surface area is many orders of magnitude lower), which is reported to have finite $\mathrm{Li}_{2} \mathrm{O}_{2}$ and $\mathrm{Li}_{2} \mathrm{O}$ solubility, ${ }^{28}$ particularly with trace amounts of $\mathrm{H}_{2} \mathrm{O} .{ }^{29}$ The minute solubility required for (partial) dissolution is illustrated by integrating the net reduction current shown in Fig. 1a and assuming a two-electron reduction formation of $\mathrm{Li}_{2} \mathrm{O}_{2}$ : Only $6 \mathrm{nmol}$ of $\mathrm{Li}_{2} \mathrm{O}_{2}$ are produced per reduction sweep, which, if dissolved into the electrolyte $(20 \mathrm{~mL})$, would give a concentration of $0.3 \mu \mathrm{M}$. Because the total number of cycles in each experiment was on the order of fewer than 30, a solubility of $\approx 10 \mu \mathrm{M}$ would support the above hypothesis, assuming a sufficiently fast dissolution rate. Unfortunately, we have no experimental means to quantify a possible solubility of $\mathrm{Li}_{2} \mathrm{O}_{2}$ at the $10 \mu \mathrm{M}$ level $(46 \mu \mathrm{g} / \mathrm{L})$, so we cannot confirm/reject this possibility. At the same time, it is also quite feasible that $\mathrm{LiO}_{2}$, which may be formed as intermediate, could be solubilized by the electrolyte as suggested by Laoire et al. ${ }^{30}$

To test this hypothesis, we extended the negative potential limit to $2.0 \mathrm{~V}_{\mathrm{Li}}$ (green dashed line in Fig. 2a), which increased the amount of ORR products by a factor of 2 (assuming $\mathrm{Li}_{2} \mathrm{O}_{2}$ ), amounting to $12 \mathrm{nmol}$ per reduction sweep. This led to an increased

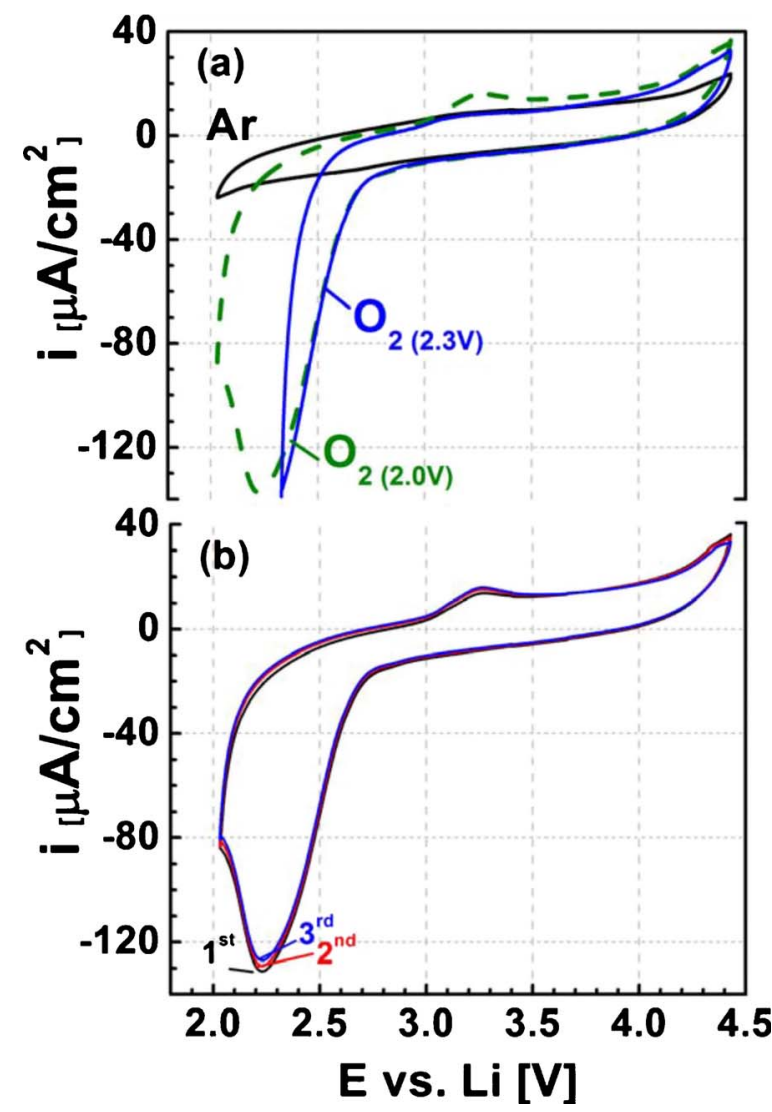

Figure 2. (Color online) $\mathrm{CVs}$ of a GC electrode in $1 \mathrm{M} \mathrm{LiClO}_{4} \mathrm{PC}: \mathrm{DME}$ $(1: 2 \mathrm{v} / \mathrm{v})$ at $5 \mathrm{mV} / \mathrm{s}$ and $100 \mathrm{rpm}$. (a) First voltammetric scans between 2.3 and 4.4 $\mathrm{V}_{\mathrm{Li}}$ in Ar (black line) and pure $\mathrm{O}_{2}$ (blue line) as well as with an extended negative potential limit of $2.0 \mathrm{~V}_{\mathrm{Li}}$ in pure $\mathrm{O}_{2}$ (green dashed line). (b) Repeat experiment under identical conditions with freshly prepared electrode, showing the first (black line), second (red line), and third (blue line) scans, indicating good reproducibility and negligible difference between the first and third scans (within $10 \mathrm{mV}$ ).

oxidation current/charge in the positive sweep (suggesting an increased amount of ORR products on or near the GC surface available for electro-oxidation), where a new oxidation peak appeared between 3.1 and $3.4 \mathrm{~V}_{\mathrm{Li}}$ and a slight increase in the oxidation current above $\approx 3.6 \mathrm{~V}_{\mathrm{Li}}$ was noted. Comparing the oxidation currents with and without rotation provides further evidence for the partial dissolution of ORR product(s). Figure 3 shows that the oxidation charge in the positive-going scan is increased in a stagnant electrolyte $(0 \mathrm{rpm})$ compared to forced convection at $100 \mathrm{rpm}$ (the amounts of electro-oxidation charge are comparable at rotations greater than $100 \mathrm{rpm}$ up to $900 \mathrm{rpm}$ ), despite the rotation rate independent ORR charge in the negative-going scan. With rotation, dissolved ORR species can move away from the GC surface into the bulk of the electrolyte, leading to the decreased electro-oxidation current. The oxidation peak between 3.1 and $3.4 \mathrm{~V}_{\mathrm{Li}}$ appears to resemble the small inflection point at $\approx 3.1 \mathrm{~V}_{\mathrm{Li}}$ in the initial charging of a $\mathrm{Li}-\mathrm{O}_{2}$ cell with a noncatalyzed carbon cathode, which was discharged to $2 \mathrm{~V}_{\mathrm{Li}} \cdot{ }^{15,18}$ The electro-oxidation rate of $\mathrm{Li}_{2} \mathrm{O}_{2}$ on carbon electrodes is nearly 0 below $4 \mathrm{~V}_{\mathrm{Li}}{ }^{17,18}$ so the anodic peak initiating near $3 \mathrm{~V}_{\mathrm{Li}}$ is not due to $\mathrm{Li}_{2} \mathrm{O}_{2}$ oxidation. However, $\mathrm{LiO}_{2}$ has only been observed as a bulk phase at $\approx 15 \mathrm{~K}^{31,32}$ and was never observed at room temperature. Therefore, the reversible potential for $\mathrm{LiO}_{2}$ decomposition is not available. However, Laoire et al. ${ }^{30}$ suggested a reversible potential of $3.0 \mathrm{~V}_{\mathrm{Li}}$ for $\mathrm{LiO}_{2}$ decomposition. Unfortunately, no references to the thermodynamic database underlying its derivation were provided. Because this oxidation peak is very close to the reversible potential for $\mathrm{Li}_{2} \mathrm{O}_{2}$ or potentially $\mathrm{LiO}_{2}$ decomposi- 


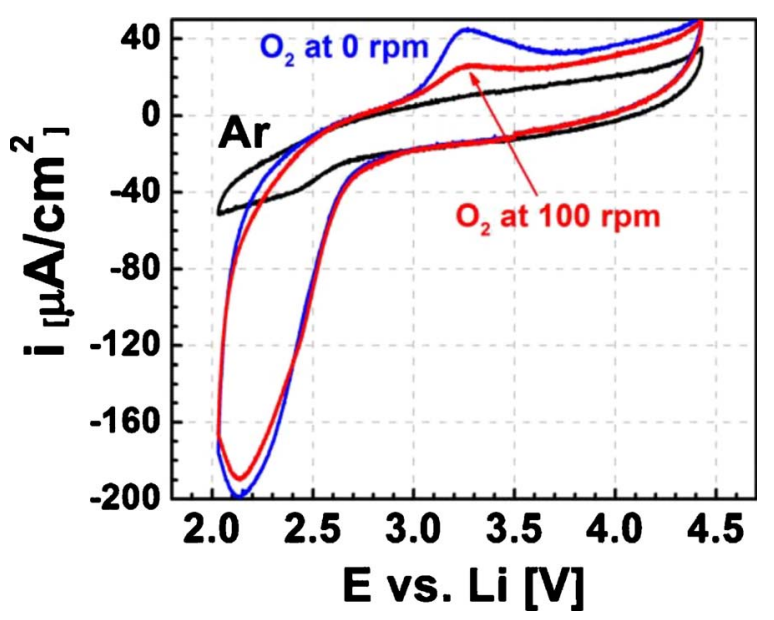

Figure 3. (Color online) CVs of a GC electrode in $1 \mathrm{M} \mathrm{LiClO}_{4} \mathrm{PC}: \mathrm{DME}$ $(1: 2 \mathrm{v} / \mathrm{v})$ in $\mathrm{Ar}$ (black line) or $\mathrm{O}_{2}$ saturated electrolyte at $20 \mathrm{mV} / \mathrm{s}$ and $0 \mathrm{rpm}$ (blue line) or $100 \mathrm{rpm}$ (red line).

tion, it is postulated that the oxidation of soluble and/or adsorbed $\mathrm{LiO}_{2}$-like species is responsible for the anodic peak between 3.1 and $3.4 \mathrm{~V}_{\mathrm{Li}}$, considering that the formation and oxidation of $\mathrm{O}_{2}^{--}$radicals in organic electrolytes in the absence of metal ions was a highly reversible reaction. ${ }^{27}$

The formation of insoluble (surface-adsorbed and/or solid) ORR products is apparent from the decrease in the reduction current with decreasing voltage at $100 \mathrm{rpm}$ (green dashed line in Fig. 2a), leading to electrode poisoning below $2.3 \mathrm{~V}_{\mathrm{Li}}$. Unlike previous studies with a positive voltage limit of $3 \mathrm{~V}_{\mathrm{Li}}$ by Aurbach and co-workers, ${ }^{26}$ which show ORR products blocking further $\mathrm{O}_{2}$ reduction on the electrode surface for $\mathrm{Au}$ and $\mathrm{Ag}$ electrodes upon subsequent cycles, ORR discharge products were removed from the electrode surface with a positive potential limit of $4.4 \mathrm{~V}_{\mathrm{Li}}$ chosen in our RDE experiments, leading to steady-state $\mathrm{CVs}$ with negligible difference in ORR activity between the first and all subsequent cycles. This is shown for the repeat experiment with a freshly prepared GC electrode in Fig. 2b, demonstrating that the first, second, and third voltammetric scans are within $\approx 10 \mathrm{mV}$ for this and all other experiments reported in this work. In these previous studies, ORR currents were only observed in the first negative-going scan on a fresh electrode, which is related to the fact that their positive voltage scan limit of $3 \mathrm{~V}_{\mathrm{Li}}$ is too low for lithium (per)oxide decomposition; ${ }^{26}$ the same was also observed in galvanostatic experiments with lithium ions $^{33}$ as well as in other studies using zinc and other metal cations. ${ }^{27}$ This good agreement with subsequent voltammetric scans thus enables the unambiguous quantification of the catalytic activity of a clean electrode surface in the potential region near the onset of the ORR current, where self-poisoning by discharge product in voltammetric scans between the selected potential window can be excluded.

Reaction order of $\mathrm{PO}_{2}$ on the ORR kinetics on well-defined GC electrodes.- Because practical Li-air batteries would be operated with air instead of oxygen, it is critical to understand the effect of oxygen partial pressure, $p_{\mathrm{O}_{2}}$, on cathode performance and its ORR kinetics. For example, for an air utilization of $\approx 50 \%$ (ratio of air consumed in the reaction over that of air supplied to the battery), typically used in proton exchange membrane fuel cells (PEMFCs), the concentration of oxygen at the exiting air stream would only be $10 \%$. While mathematical modeling of oxygen mass transport in electrolyte-flooded pores of a $\mathrm{Li}$-air cathode shows that lowering $p_{\mathrm{O}_{2}}$ reduces its discharge capacity, ${ }^{19}$ supported by the experimentally observed, reduced capacity when using electrolytes with low oxygen solubility or when using low oxygen partial pressures, ${ }^{21}$ we

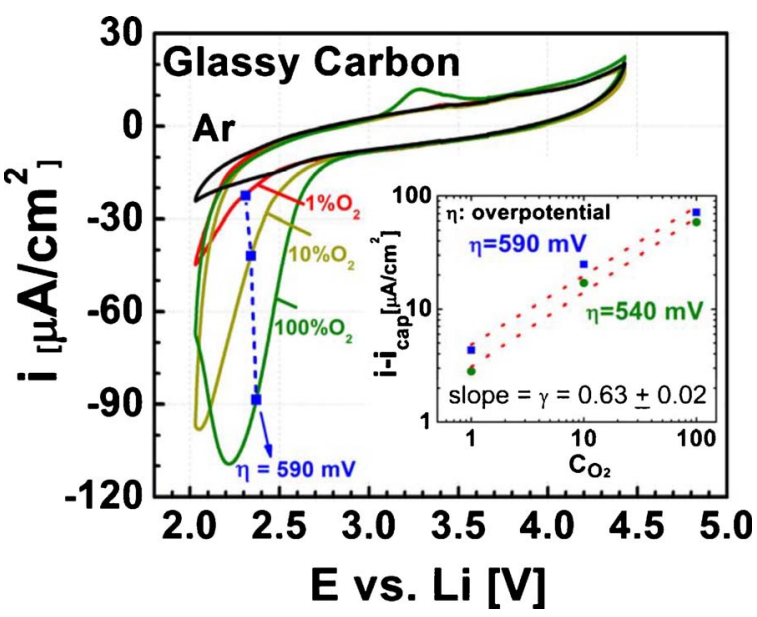

Figure 4. (Color online) $\mathrm{CV}$ s of a $\mathrm{GC}$ electrode in $1 \mathrm{M} \mathrm{LiClO}_{4} \mathrm{PC}: \mathrm{DME}$ $(1: 2 \mathrm{v} / \mathrm{v})$ in $\mathrm{Ar}$ and 1,10 , and $100 \% \mathrm{O}_{2}$ at $5 \mathrm{mV} / \mathrm{s}$ and $900 \mathrm{rpm}$. The inset shows the ORR reaction order, $\gamma$, with respect to oxygen concentration obtained at constant overpotentials, $\eta$ (i.e., $\eta=540$ and $590 \mathrm{mV}$ based on $E_{\text {rev } \mathrm{Li}_{2} \mathrm{O}_{2}}=2.96 \mathrm{~V}_{\mathrm{Li}}$ for $100 \% \mathrm{O}_{2}$ ).

report, for the first time, the reaction order with respect to oxygen partial pressure obtained for the ORR kinetics in aprotic organic electrolytes.

The significant negative shift of the cell voltage with decreasing $p_{\mathrm{O}_{2}}$ from 100 to $1 \% \mathrm{O}_{2}$ in Fig. 4 can be deconvoluted into kinetic and thermodynamic effects by a simple kinetic analysis assuming Tafel kinetics for the ORR current density, $i_{\mathrm{ORR}}$ (commonly used to model the ORR kinetics in PEMFCs ${ }^{34}$ )

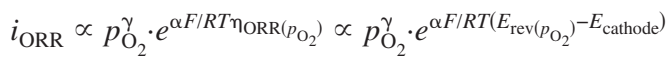

where $\gamma$ is the reaction order with respect to $p_{\mathrm{O}_{2}}, \alpha$ is the cathodic transfer coefficient, $T$ and $F$ are temperature and the Faraday constant, and $\eta_{\text {ORR }}$ is the overpotential of the cathode reaction. The so-called Tafel slope is defined as $2.303 R T /(\alpha F)$. Conducting the analysis under the assumption that $\mathrm{Li}_{2} \mathrm{O}_{2}$ is the major discharge product on noncatalyzed carbon (consistent with ex situ Raman ${ }^{5}$ and also assumed in recent density functional theory calculations ${ }^{9}$ ), $\eta_{\mathrm{ORR}}$ is the difference between the $p_{\mathrm{O}_{2}}$-dependent reversible potential for $\mathrm{Li}_{2} \mathrm{O}_{2}$ formation, $E_{\mathrm{rev}\left(p_{\mathrm{O}_{2}}\right)}$ [amounting to $2.303 R T /(2 F)$ $\approx 30 \mathrm{mV}$ per decade of $p_{\mathrm{O}_{2}}$ described by the Nernst equation], and the actual cathode potential. Therefore, the dependence of ORR current density with oxygen partial pressure at a constant cathode potential contains both the purely kinetic term $\gamma$ and a thermodynamic term due to the $p_{\mathrm{O}_{2}}$ dependence of the equilibrium potential, $E_{\mathrm{rev}\left(p_{\mathrm{O}_{2}}\right)}$

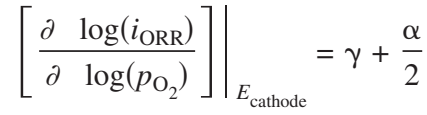

However, if evaluated at a constant overpotential, the decrease in the $i_{\mathrm{ORR}}$ with $p_{\mathrm{O}_{2}}$ only depends on the kinetic parameter $\gamma$, which provides insights into the ORR reaction mechanism

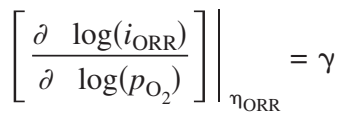

As shown in the inset of Fig. 4, $\gamma$ is determined to be $0.63 \pm 0.02$ at overpotentials of 540 and $590 \mathrm{mV}$. These values are quite similar to what was reported for PEMFC cathodes $(\gamma \approx 0.5),{ }^{34}$ and the significant dependence of $p_{\mathrm{O}_{2}}$ on the ORR current suggests that the initial adsorption of oxygen is a rate-determining step on GC electrodes, which is probably related to the relatively weak carbonoxygen bond strength $[\approx 1.8 \mathrm{eV}$ for $\mathrm{O}$ adsorption on graphite $(001)]^{35}$ 


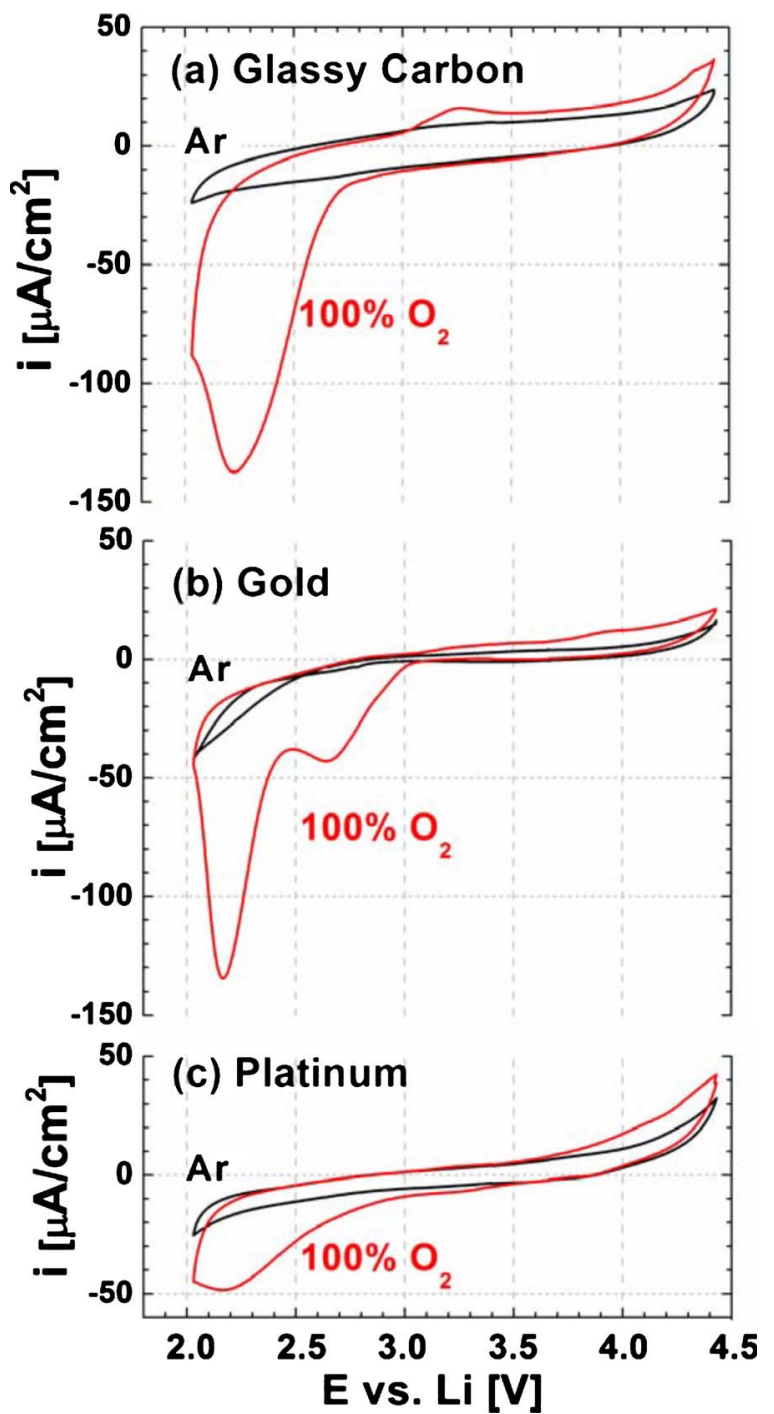

Figure 5. (Color online) CVs of (a) GC, (b) Au, and (c) Pt electrode in $1 \mathrm{M}$ $\mathrm{LiClO}_{4} \mathrm{PC}$ :DME $(1: 2 \mathrm{v} / \mathrm{v})$ purged with either Ar or $100 \% \mathrm{O}_{2}(5 \mathrm{mV} / \mathrm{s}$ and $100 \mathrm{rpm})$.

Intrinsic catalytic activity comparison of $G C, A u$, and Pt.While there are some studies on the effect of several well-defined surfaces on the ORR/OER kinetics in aprotic organic electrolytes with tetraalkylammonium salts, ${ }^{27,33}$ Fig. 5 shows, for the first time, an intrinsic ORR activity comparison for well-defined surfaces of $\mathrm{GC}$ as well as polycrystalline Au and Pt electrodes in the presence of lithium cations in $100 \% \mathrm{O}_{2}$, together with base CVs in Ar. Similar to GC electrodes (Fig. 1c and 2b), there were no observable activity differences between the first and any subsequent voltammetric scans for Pt. However, the activity of Au electrodes increased in the first few cycles before reaching a steady state. We observed the same behavior in the first three discharge/charge cycles in $\mathrm{Li}-\mathrm{O}_{2}$ singlecell battery tests with $\mathrm{Au} / \mathrm{C}$ cathodes and tentatively ascribed it to electrochemical surface cleaning effects during potential cycling. For comparison purposes, only the steady-state CVs are shown in Fig. 5a-c. Compared to GC (Fig. 5a) and Pt (Fig. 5c), the Au electrode (Fig. 5b) shows two features in the oxygen reduction region; more importantly, however, the onset of the ORR is at a significantly more positive potential for the Au electrode, indicating its high catalytic activity. As observed for GC electrodes, the oxidation charge in the positive-going scans of $\mathrm{Au}$ and $\mathrm{Pt}$ electrodes is also about 1 order of magnitude lower than the reduction charge in the negativegoing scans (see above discussion). The oxidation feature near
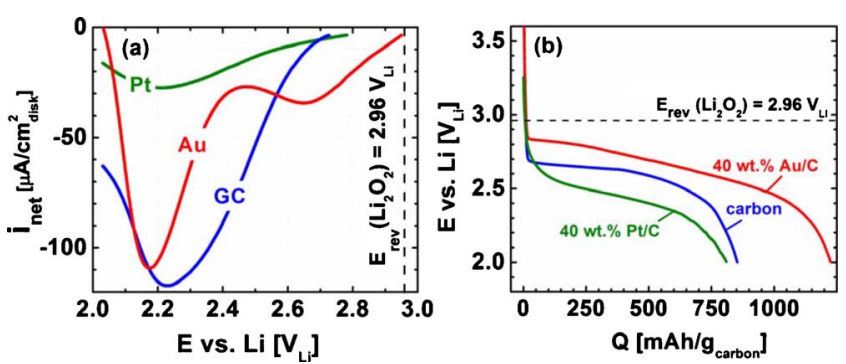

Figure 6. (Color online) (a) RDE: ORR net current densities, $i_{\text {net }}$, on GC and polycrystalline $\mathrm{Pt}$ and $\mathrm{Au}$ in pure $\mathrm{O}_{2}$ at $100 \mathrm{rpm}$ and $5 \mathrm{mV} / \mathrm{s}$. Net current densities for the ORR were obtained by up-shifting (by $\leq 3.4 \mu \mathrm{A} / \mathrm{cm}^{2}$ ) the reduction current in $\mathrm{O}_{2}$ so that the net ORR current after capacitive correction is zero at $E_{\text {rev }}=2.96 \mathrm{~V}_{\mathrm{Li}}$. (b) $\mathrm{Li}-\mathrm{O}_{2}$ single cells: Discharge profiles (second discharge) at $0.1 \mathrm{~mA} / \mathrm{cm}^{2}$ corresponding to $\approx 150 \mathrm{~mA} / \mathrm{g}_{\mathrm{C}}$ (carbon) or $\approx 250 \mathrm{~mA} / \mathrm{g}_{\mathrm{C}}(\mathrm{Au} / \mathrm{C}$ and $\mathrm{Pt} / \mathrm{C})$.

$3 \mathrm{~V}_{\mathrm{Li}}$ is most pronounced on $\mathrm{GC}$, barely visible on $\mathrm{Au}$, and absent on Pt electrodes. If this feature were indeed related to the electrooxidation of $\mathrm{LiO}_{2}$-like species, this trend could be understood by the increasing oxygen bond energy from carbon $(\approx 1.8 \mathrm{eV})^{35}$ to $\mathrm{Au}$ $(\approx 2.7 \mathrm{eV})^{36}$ to $\mathrm{Pt}(\approx 4.2 \mathrm{eV})^{36}$ because higher oxygen-substrate bond energies would favor the formation of more oxidized species (i.e., $\mathrm{Li}_{2} \mathrm{O}_{2}$ and $\mathrm{Li}_{2} \mathrm{O}$ ).

To better compare the intrinsic catalytic activity of the different model electrodes, capacitive and background-corrected current densities obtained from the negative-going sweeps of the voltammograms in Fig. 5 are shown in Fig. 6a, comparing the net ORR current density vs potential. The onset of oxygen reduction on Au occurs essentially at the $\mathrm{Li}_{2} \mathrm{O}_{2}$ equilibrium voltage, indicating its high ORR activity. Significantly lower onset potentials were observed for $\mathrm{Pt}$ $\left(\approx 2.8 \mathrm{~V}_{\mathrm{Li}}\right)$ and $\mathrm{GC}\left(\approx 2.75 \mathrm{~V}_{\mathrm{Li}}\right)$, whereby the potential dependence on Pt is very weak, probably due to strong solvent adsorption, so that GC becomes more active than $\mathrm{Pt}$ below $\approx 2.7 \mathrm{~V}_{\mathrm{Li}}$. This effect explains the previously reported similar discharge voltages with and without platinum in carbon-based electrodes. ${ }^{5}$ This is a rather perplexing result because $\mathrm{Pt}$ is the most active ORR catalyst in both acidic and alkaline aqueous electrolytes, ${ }^{37}$ while $\mathrm{Au}{ }^{38}$ and carbon $^{39}$ are quite inactive in acid electrolyte and have low activity in alkaline electrolyte ${ }^{39-41}$ (also shown in Fig. 7, discussed below).

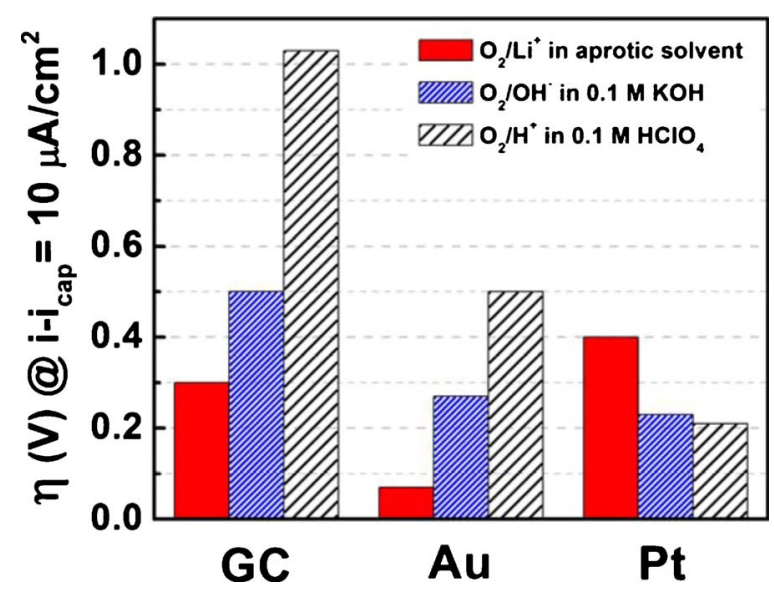

Figure 7. (Color online) Overpotentials for the ORR at a net ORR current density $\left(i-i_{\text {cap }}\right)$ of $10 \mu \mathrm{A} / \mathrm{cm}^{2}$ in $1 \mathrm{M} \mathrm{LiClO}_{4} \mathrm{PC}: \mathrm{DME}(1: 2 \mathrm{v} / \mathrm{v})$ (red, data from Fig. 6a using $E_{\text {rev }}=2.96 \mathrm{~V}_{\mathrm{Li}}$ ), in $0.1 \mathrm{M} \mathrm{KOH}$ (blue, using $E_{\text {rev }}$ $=1.23 \mathrm{~V}_{\mathrm{RHE}}$ ), and in $0.1 \mathrm{M} \mathrm{HClO}_{4}$ (black, using $E_{\text {rev }}=1.23 \mathrm{~V}_{\mathrm{RHE}}$ ). ORR activities in aqueous electrolyte were obtained for the positive-going scans $(10 \mathrm{mV} / \mathrm{s})$ in oxygen-saturated electrolyte at $900 \mathrm{rpm}$. 
Discharge voltage comparison of $\mathrm{Li}_{-} \mathrm{O}_{2}$ air electrodes with Vulcan, $A u / C$, and $P t / C$. - To verify that the ORR activity trends obtained by RDE measurements can be related to the Li-air battery discharge voltage, air electrodes with Vulcan carbon only and with $\mathrm{Au}$ or Pt-catalyzed Vulcan carbon $(40 \mathrm{wt} \% \mathrm{Au} / \mathrm{C}$ or $40 \mathrm{wt} \% \mathrm{Pt} / \mathrm{C})$ were tested in $\mathrm{Li}-\mathrm{O}_{2}$ single cells at a discharge rate of $0.1 \mathrm{~mA} / \mathrm{cm}_{\text {electrode }}^{2}$ (corresponding to $\approx 150 \mathrm{~mA} / \mathrm{g}_{\mathrm{C}}$ for carbon or $\approx 250 \mathrm{~mA} / \mathrm{g}_{\mathrm{C}}$ for $\mathrm{Au} / \mathrm{C}$ and $\mathrm{Pt} / \mathrm{C}$ due to minor differences in carbon loading). Figure $6 \mathrm{~b}$ shows that the same ORR activity trends are observed in $\mathrm{Li}-\mathrm{O}_{2}$ single-cell discharge curves for cathodes with either carbon, $40 \mathrm{wt} \% \mathrm{Pt} / \mathrm{C}$, or $40 \mathrm{wt} \% \mathrm{Au} / \mathrm{C}$, whereby the onset voltage of $\approx 2.8 \mathrm{~V}_{\mathrm{Li}}$ and the average voltage plateau of $\approx 2.7 \mathrm{~V}_{\mathrm{Li}}$ of 40 wt $\% \mathrm{Au} / \mathrm{C}$ are higher than those of manganese-oxide-based catalysts at lower $\left(70 \mathrm{~mA} / \mathrm{g}_{\mathrm{C}}\right)^{10,14,15}$ or equal discharge currents $\left(0.1 \mathrm{~mA} / \mathrm{cm}^{2}\right) .{ }^{11}$ The lower discharge voltage on $40 \mathrm{wt} \% \mathrm{Pt} / \mathrm{C}$ of $\approx 2.5 \mathrm{~V}_{\mathrm{Li}}$ may be rationalized by a lower effective carbon surface area of this catalyst (estimated $>25 \%$ lower carbon surface area considering $\approx 30 \mathrm{~m}_{\mathrm{Pt}}^{2} / \mathrm{g}_{\text {catalyst }}$ and $\approx 60 \mathrm{~m}_{\mathrm{C}}^{2} / \mathrm{g}_{\text {catalyst }}$ using the external surface areas of $\mathrm{Pt}$ and Vulcan). ${ }^{18}$ The voltage difference between the carbon and the $\mathrm{Au} / \mathrm{C}$ cathode remains at $\approx 100 \mathrm{mV}$ through the whole discharge capacity, demonstrating that the discharge products are not uniformly covering the catalyst surface and that the ORR happens on the catalyst surface instead of occurring on the discharge product surface. This seems to be very analogous to what was observed in PEMFC operation at $-20^{\circ} \mathrm{C}$, where the ORR activity of $\mathrm{Pt}$ forming solid ice $\left[2 \mathrm{H}^{+}+0.5 \mathrm{O}_{2}+2 \mathrm{e}^{-}\right.$ $\left.\rightarrow\left(\mathrm{H}_{2} \mathrm{O}\right)_{\text {solid }}\right]$ is maintained until nearly $100 \%$ of the electrode void volume is filled with ice, which suggests that the solid reaction product is formed at the Pt surface and is being continuously pushed into the void space of the electrode. ${ }^{42}$ A more quantitative ORR activity comparison between $\mathrm{RDE}$ and $\mathrm{Li}-\mathrm{O}_{2}$ single cells, again, requires that the same catalysts are used in either method, and we are currently developing an RDE method for supported catalysts.

Specific discharge capacities of $\mathrm{Li}-\mathrm{O}_{2}$ cells at $0.1 \mathrm{~mA} / \mathrm{cm}_{\text {electrode }}^{2}$ or $250 \mathrm{~mA} / \mathrm{g}_{\mathrm{C}}$ (Fig. 6b) with $\mathrm{Au} / \mathrm{C}$ were $\approx 1500 \mathrm{mAh} / \mathrm{g}_{\mathrm{C}}$, which is roughly 2-3 times lower than that reported for $\mathrm{MnO}_{x}$-based cathodes discharged at a lower rate of $70 \mathrm{~mA} / \mathrm{g}_{\mathrm{C}} \cdot{ }^{10,14}$ The difference is likely due to the generally observed increase in specific capacity with decreasing current densities. ${ }^{19,21,22}$ However, only $\approx 800 \mathrm{mAh} / \mathrm{g}_{\mathrm{C}}$ were observed for pure Vulcan and $\mathrm{Pt} / \mathrm{C}$ electrodes. Because all our cathodes have the same carbon loading and thickness and because the void volume fraction of catalyzed and noncatalyzed Vulcan carbon electrodes is essentially the same (the metal volume fraction is negligible), ${ }^{23}$ all of our cathodes should have the same available volume for $\mathrm{Li}_{x} \mathrm{O}_{2}$ storage. Because the latter strongly affects specific discharge capacities, ${ }^{6}$ one would expect to obtain similar specific capacities for our cathodes, independent of the catalyst. Although it is relatively straightforward to relate the enhanced ORR kinetics of $\mathrm{Au} / \mathrm{C}$ to increased discharge voltages, the substantially higher discharge specific capacity for $\mathrm{Au} / \mathrm{C}$ (reproducible over three cells) compared to carbon and $\mathrm{Pt} / \mathrm{C}$ is not understood. We suggest that different catalysts may yield different reaction products $\left(\mathrm{LiO}_{2}, \mathrm{Li}_{2} \mathrm{O}\right.$, or $\left.\mathrm{Li}_{2} \mathrm{O}_{2}\right)$, analogous to the ORR in aqueous electrolytes with predominantly $\mathrm{H}_{2} \mathrm{O}_{2}$ on $\mathrm{Au}$ and $\mathrm{C}$, in contrast to $\mathrm{H}_{2} \mathrm{O}$ on $\mathrm{Pt}$ (see discussion later). Thus a variation in discharge product formation/distribution in the cathode may affect the discharge capacity, which needs to be examined in future studies.

Comparison with proposed ORR mechanisms in the absence of metal cations and protons. - The strong catalytic sensitivity of the ORR activity in PC:DME $\left(1: 2 \mathrm{v} / \mathrm{v}\right.$ ) in the presence of $\mathrm{Li}^{+}$(with $\mathrm{Au} \gg \mathrm{C}>\mathrm{Pt}$ ) shown in this study is in stark contrast to the insensitivity of the ORR activity to the electrode surface in aprotic solvents in the absence of protons or metal cations. ${ }^{27,43}$ Before proposing a possible reaction mechanism for the poorly understood ORR in aprotic organic electrolytes in the presence of $\mathrm{Li}^{+}$, it is instructive to review what is known about the ORR in similar solvents when only large cations such as tetrabutylammonium $\left(\mathrm{TBA}^{+}\right)$or tetraethylam- monium $\left(\mathrm{TEA}^{+}\right)$are present (e.g., $\mathrm{TBA}^{+}$and $\mathrm{TEA}^{+}$perchlorates as TBAP and TEAP, respectively). In this case, many previous studies suggest that ORR proceeds by one electron transfer to form the superoxide radical $\left(\mathrm{O}_{2}^{-}\right)$as a weakly adsorbed species, followed by its subsequent solvation by $\mathrm{TBA}^{+}$or $\mathrm{TEA}^{+26,27,33,44}$

$$
\mathrm{O}_{2}+\mathrm{e}^{-} \rightarrow\left(\mathrm{O}_{2}^{\cdot-}\right)_{\text {weakly adsorbed }} \rightarrow\left(\mathrm{TBA}^{+} \mathrm{O}_{2}^{--}\right)_{\text {dissolved }}
$$

For example, Maricle and Hodgson ${ }^{44}$ deduced the formation of $\mathrm{O}_{2}^{--}$ in dimethylformamide (DMF) containing TBAP from cyclic voltammetry and electron spin resonance data. Similarly, Aurbach and co-workers ${ }^{26}$ suggested the formation and oxidation (reversibly) of superoxide ion in $\mathrm{O}_{2}$-saturated DME with TBAP on $\mathrm{Au}$ and $\mathrm{Ag}$. More recently, Laoire et $\mathrm{al}^{30}$ reported high reversibility for the ORR/OER on GC in acetonitrile (MeCN) with TBAP salt, with a reversible redox potential of $\approx-0.83 \mathrm{~V}$ vs $\mathrm{Ag} / \mathrm{AgCl}\left(\approx 2.10 \mathrm{~V}_{\mathrm{Li}}\right)$ for Reaction 6; the large diffusion-limited currents in their RDE measurements support the facile dissolution of the reduction product(s) in the electrolyte and also confirm a one-electron reduction of oxygen, perfectly consistent with Reaction 6 . In addition, nearly identical ORR activities and high reversibility reported for $\mathrm{Pt}, \mathrm{Au}$, and mercury electrodes in dimethylsulfoxide (DMSO) with TEAP, as well as for $\mathrm{Pt}, \mathrm{Au}$, and carbon electrodes in DMSO, DMF, and pyridine solvents with TEAP, ${ }^{27}$ led to the conclusion that the ORR in aprotic electrolytes with large cations is a catalytically insensitive reaction, ${ }^{43}$ consistent with a weakly adsorbed superoxide radical.

In contrast to the nearly reversible reduction of $\mathrm{O}_{2}$ to a solvated superoxide species [e.g., $\left(\mathrm{TBA}^{+} \mathrm{O}_{2}^{--}\right)_{\text {dissolved }}$ in the above-described electrolytes, the replacement of large cations with lithium ions in $\mathrm{MeCN}$ results in a positive shift of the onset of the ORR to $\approx 2.7 \mathrm{~V}_{\mathrm{Li}}{ }^{30}{ }^{30}$ Despite this positive potential shift of the ORR current, the increase in the reversible potential from $\approx 2.1 \mathrm{~V}_{\mathrm{Li}}$ with TBAP cations to 2.96 or $2.91 \mathrm{~V}_{\mathrm{Li}}$ with $\mathrm{Li}$ ions when $\mathrm{Li}_{2} \mathrm{O}_{2}$ or $\mathrm{Li}_{2} \mathrm{O}$ is formed, respectively, results in a large overpotential $(\approx 0.3 \mathrm{~V})$ observed on GC in the presence of $\mathrm{Li}^{+}$, which reflects significant irreversibility of the ORR with $\mathrm{Li}$ ions in aprotic electrolytes. In addition, the extremely low solubility of lithium (per)oxides and other metal (per)oxides in aprotic solvents leads to the formation of surface films that can poison the electrode in subsequent cycles (ORR currents can only be observed in the first voltammetric scan if these surface films are not removed on the oxidation sweep at voltages no greater than $\left.3 \mathrm{~V}_{\mathrm{Li}}\right)^{26,27}$

Proposed ORR mechanisms in $\mathrm{Li}^{+}$-containing aprotic solvents. - We propose here the ORR mechanism in $\mathrm{Li}^{+}$-containing aprotic solvents. The first step in the ORR in $\mathrm{Li}^{+}$-containing aprotic solvents may proceed according to

$$
\mathrm{O}_{2}+\mathrm{e}^{-} \rightarrow\left(\mathrm{O}_{2}^{--}\right)_{\text {weakly adsorbed }}
$$

forming superoxide radicals as a weakly adsorbed species, which might be subsequently solvated by various species such as salt cations $\left(\mathrm{TBA}^{+}, \mathrm{TEA}^{+}\right.$, or $\mathrm{Li}^{+}$) or solvents $(\mathrm{PC})^{26}$ and then diffuse into the bulk of the electrolyte, particularly when the electrode is rotated (RDE method)

$$
\begin{aligned}
& \left(\mathrm{O}_{2}^{--}\right)_{\text {weakly adsorbed }}^{+\mathrm{Y}\left(\mathrm{Y}^{2}=\mathrm{TBA}^{+}, \mathrm{TEA}^{+},{\left.\mathrm{PC}, \mathrm{Li}^{+}\right)}^{\rightarrow}\right.}\left(\mathrm{YO}_{2}\right)_{\text {dissolved }} \\
& \text { RDE } \\
& \rightarrow \text { bulk electrolyte }
\end{aligned}
$$

which is consistent with the observed imbalance of cathodic and anodic charges. Alternatively, the weakly adsorbed superoxide radicals could react with $\mathrm{Li}^{+}$to form surface-adsorbed $\mathrm{LiO}_{2}$

$$
\left(\mathrm{O}_{2}^{\circ-}\right)_{\text {weakly adsorbed }}+\mathrm{Li}^{+} \rightarrow\left(\mathrm{LiO}_{2}\right)_{\text {adsorbed }}
$$

The sum of Reaction $7 \mathrm{a}$ and $7 \mathrm{c}$ corresponds to the first reduction step proposed in a recent DFT study on the ORR in Li-air batteries. ${ }^{9}$ Furthermore, the species $\left(\mathrm{YO}_{2}\right)_{\text {dissolved }}$ for $\mathrm{Y}=\mathrm{Li}$ in Eq. $7 \mathrm{~b}$ could also diffuse and adsorb onto the active surface to form surface- 
adsorbed $\mathrm{LiO}_{2}$, particularly for a very small ratio of electrolyte volume to electrode surface area as in a $\mathrm{Li}-\mathrm{O}_{2}$ cell

$$
\left(\mathrm{LiO}_{2}\right)_{\text {dissolved }} \underset{\text { cell }}{\rightarrow}\left(\mathrm{LiO}_{2}\right)_{\text {adsorbed }}
$$

The subsequent dominant pathways are considered strongly dependent on the oxygen adsorption nature of the catalyst surface. In the relatively weak oxygen chemisorptions (e.g., carbon), the surfaceadsorbed $\mathrm{LiO}_{2}$ can be reduced to $\mathrm{Li}_{2} \mathrm{O}_{2},{ }^{9}$ which is supported by the fact that $\mathrm{Li}_{2} \mathrm{O}_{2}$ has been detected on the surfaces of carbon and carbon- $\mathrm{MnO}_{2}$ composites by ex situ Raman spectroscopy ${ }^{5,10}$

$$
\left(\mathrm{LiO}_{2}\right)_{\text {adsorbed }}+\mathrm{e}^{-}+\mathrm{Li}^{+} \rightarrow\left(\mathrm{Li}_{2} \mathrm{O}_{2}\right)_{\text {solid }}
$$

Further reduction of $\mathrm{Li}_{2} \mathrm{O}_{2}$ to $\mathrm{Li}_{2} \mathrm{O}$ is thermodynamically possible in the typical discharge potential range of $\mathrm{Li}-\mathrm{O}_{2}$ batteries $\left(2.8-2.0 \quad \mathrm{~V}_{\mathrm{Li}}\right)$

$$
\begin{aligned}
\left(\mathrm{Li}_{2} \mathrm{O}_{2}\right)_{\text {solid }}+2 \mathrm{e}^{-}+2 \mathrm{Li}^{+} \rightarrow & 2\left(\mathrm{Li}_{2} \mathrm{O}\right)_{\text {solid }} \\
& \text { with } E_{\text {rev }}=2.86 \mathrm{~V}_{\mathrm{Li}}
\end{aligned}
$$

which is not an elementary step. However, in the catalysts forming a strong bond with atomic oxygen, e.g., in Pt in contrast to carbon $\left(\approx 4.2 \mathrm{eV}^{36}\right.$ vs $\left.\approx 1.8 \mathrm{eV}^{35}\right)$, the ORR in aprotic electrolytes with lithium ions may mostly proceed via a reaction mechanism analogous to that established for the ORR on platinum metals in aqueous electrolytes ${ }^{45}$

$$
\begin{gathered}
\left(\mathrm{LiO}_{2}\right)_{\text {adsorbed }}+\mathrm{e}^{-}+\mathrm{Li}^{+} \rightarrow\left(\mathrm{Li}_{2} \mathrm{O}\right)_{\text {solid }}+\mathrm{O}_{\text {adsorbed }} \\
\mathrm{O}_{\text {adsorbed }}+\mathrm{e}^{-}+\mathrm{Li}^{+} \rightarrow(\mathrm{LiO})_{\text {adsorbed }} \\
(\mathrm{LiO})_{\text {adsorbed }}+\mathrm{e}^{-}+\mathrm{Li}^{+} \rightarrow\left(\mathrm{Li}_{2} \mathrm{O}\right)_{\text {adsorbed }}
\end{gathered}
$$

Considering the ORR pathways outlined above, the nature of the ORR products are likely to depend on the catalyst, with a preference for $\mathrm{Li}_{2} \mathrm{O}_{2}$ formation for catalysts that have low oxygen adsorption strength (e.g., $\mathrm{C}$ ) and a preference for $\mathrm{Li}_{2} \mathrm{O}$ for catalysts with high oxygen catalyst bond strength (e.g., Pt). Unfortunately, no literature data are available on the discharge product distribution as a function of catalyst and this will be examined in our future work.

Comparison with the proposed ORR mechanisms in acid and alkaline solutions.- Some supports for the above-proposed catalyst-dependent reaction pathways can be found by comparing the ORR activities of different catalysts in $\mathrm{Li}^{+}$-containing aprotic solvents (see Fig. 6a) with those in aqueous electrolytes. As shown in Fig. 7, the ORR overpotentials at a net kinetic current density of $10 \mu \mathrm{A} / \mathrm{cm}_{\text {disk }}^{2}$ in PC:DME $(1: 2 \mathrm{v} / \mathrm{v})$ with $1 \mathrm{M} \mathrm{LiClO}_{4}$ (red, data taken from Fig. 6a) are compared with those in either $0.1 \mathrm{M} \mathrm{KOH}$ (blue ) or $0.1 \mathrm{M} \mathrm{HClO}_{4}$ (black) measured in our laboratory. A benchmark current density of $10 \mu \mathrm{A} / \mathrm{cm}_{\text {disk }}^{2}$ for smooth disk electrodes was chosen because it corresponds to the long-term performance target of Li-air cathodes of $10 \mathrm{~mA} / \mathrm{cm}_{\text {electrode }}^{2}$ for assumed typical catalyst loadings of $1 \mathrm{mg}_{\text {catalyst }} / \mathrm{cm}_{\text {cathode }}^{2}$ and typical catalyst specific surface areas of $100 \mathrm{~m}_{\text {catalyst }}^{2} / \mathrm{g}_{\text {catalyst }}$.

The most striking dependence of the ORR overpotential on $\mathrm{pH}$ is noted for GC (Fig. 7), with $\approx 0.53 \mathrm{~V}$ higher overpotential in acid electrolyte $\left(\mathrm{pH} \approx 1, \eta=1.03 \mathrm{~V}\right.$ at $\left.10 \mu \mathrm{A} / \mathrm{cm}^{2}\right)$ compared to alkaline electrolyte $\left(\mathrm{pH} \approx 13, \eta=0.50 \mathrm{~V}\right.$ at $\left.10 \mu \mathrm{A} / \mathrm{cm}^{2}\right)$, which agrees well with the literature. ${ }^{39}$ As proposed previously for the pH-dependent ORR activity on $\mathrm{Au},{ }^{38}$ this behavior can be rationalized by assuming that the initial reduction of oxygen to the superoxide radical is the rate-determining ORR step for catalysts with very weak oxygen adsorption strength

$$
\mathrm{O}_{2}+\mathrm{e}^{-} \rightarrow\left(\mathrm{O}_{2}^{--}\right)_{\text {weakly adsorbed }}
$$

with $E_{\text {rev }}=-0.30 \mathrm{~V}$ vs SHE (Ref. 38) [10]

Because the ORR reversible potential measured vs the standard hy-

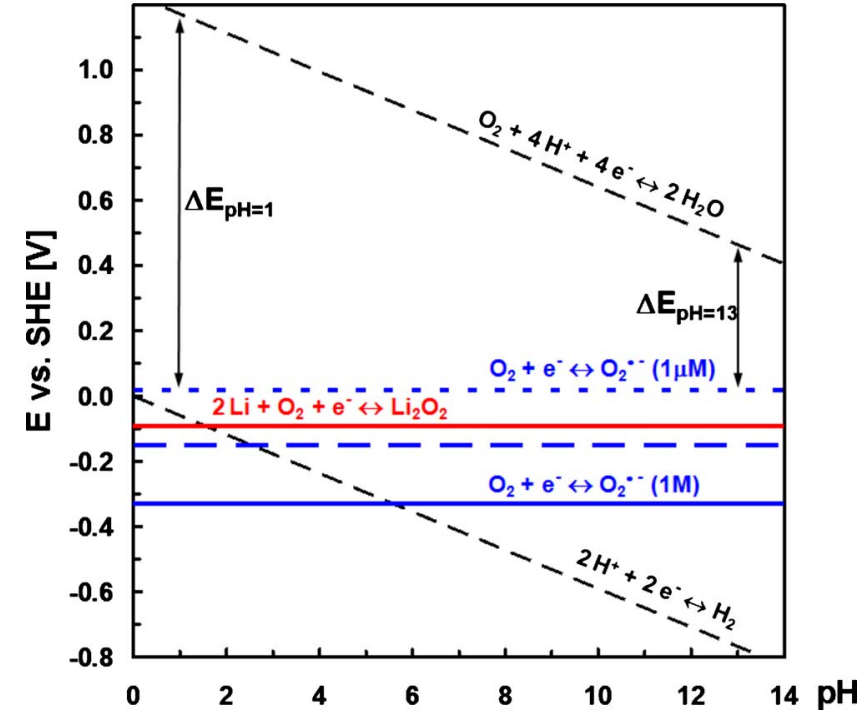

Figure 8. (Color online) Modified Pourbaix diagram ${ }^{38}$ for lithium peroxide with the equilibria for the superoxide/oxygen reaction.

drogen electrode (SHE) decreases with increasing $\mathrm{pH}\left(E_{\text {rev(ORR })}\right.$ $=1.23-0.059 \mathrm{~V} / \mathrm{pH})$, the difference in reversible potential between Eq. 10 (independent of $\mathrm{pH}$ ) and $E_{\mathrm{rev}(\mathrm{ORR})}$ is reduced from acid to alkaline (this is illustrated in the Pourbaix diagram shown in Fig. 8). This further implies lower ORR overpotentials with increasing $\mathrm{pH}$ if Reaction 10 were rate determining (this concept was illustrated very clearly by Blizanac et $\mathrm{al}^{38}$ ). From the thermodynamic standpoint, the expected decrease in the ORR overpotential on GC between $\mathrm{pH} 1$ and 13 would be $\approx 0.71 \mathrm{~V}$ (viz. $12 \times 0.059 \mathrm{~V}$ ), which compares reasonably well with the observed difference of $0.63 \mathrm{~V}$ (Fig. 7), providing support to the hypothesis that Reaction 10 is rate determining for the ORR on GC in aqueous electrolytes. In addition, the sole ORR product on GC in aqueous electrolytes is $\mathrm{H}_{2} \mathrm{O}_{2}{ }^{39}$ rather than $\mathrm{H}_{2} \mathrm{O}$. Assuming a similar ORR reaction mechanism on GC in aprotic electrolytes in the presence of lithium ions would suggest that Reaction $7 \mathrm{a}$ is likely to be rate determining. In this case, the much lower overpotential in the aprotic compared to the aqueous electrolytes (Fig. 7) could be attributed to the fact that the reversible potential for Reaction $10(-0.30 \mathrm{~V}$ vs SHE) is much closer to that for the reduction of oxygen with $\mathrm{Li}$ ions to form $\mathrm{Li}_{2} \mathrm{O}_{2}$ (e.g., $E_{\mathrm{rev}\left(\mathrm{Li}_{2} \mathrm{O}_{2}\right)}=2.96 \mathrm{~V}_{\mathrm{Li}} \equiv-0.07 \mathrm{~V}$ vs $\mathrm{SHE}$ ) or $\mathrm{Li}_{2} \mathrm{O}$ in comparison to the reversible ORR potentials in aqueous electrolytes, as shown in Fig. $8 .^{38}$

Unlike GC, ORR on $\mathrm{Pt}$ in aqueous electrolytes proceeds all the way to $\mathrm{H}_{2} \mathrm{O}^{25,46}$ and the ORR overpotentials do not depend on $\mathrm{pH}$ (Fig. 7), consistent with the nearly identical ORR activity in $0.1 \mathrm{M}$ $\mathrm{KOH}^{46,47}$ and $0.1 \mathrm{M} \mathrm{HClO}_{4}{ }^{46,48}$ This observation suggests that the rate-determining step has the same $\mathrm{pH}$ dependency as $E_{\mathrm{rev}\left(\mathrm{H}_{2} \mathrm{O}\right)}$ $(0.059 \mathrm{~V} / \mathrm{pH})$, which is satisfied for Reaction $9 \mathrm{a}-9 \mathrm{c}$, when "Li" is replaced by "H," expressing the notion that the strong Pt-O bond favors the dissociation of $\mathrm{O}_{2}$ and the formation of $\mathrm{H}_{2} \mathrm{O}$ as the final ORR product. By analogy, one would thus expect that the ORR in $\mathrm{Li}^{+}$-containing aprotic electrolytes on $\mathrm{Pt}$ leads to the formation of $\mathrm{Li}_{2} \mathrm{O}$ rather than $\mathrm{Li}_{2} \mathrm{O}_{2}$. Unlike GC, the ORR overpotential on Pt in the $\mathrm{Li}^{+}$-containing aprotic electrolyte is higher than that in aqueous electrolytes, and this difference is not understood. One possible explanation is the strong adsorption of organic molecules and $\mathrm{O}_{\text {adsorbed }}$ (in Reaction 9a) on platinum and the associated poisoning of its ORR activity. We have obtained some evidence to support that $\mathrm{Pt}$ strongly interacts with PC:DME, as shown in Fig. 9, where the addition of millimolar quantities of PC:DME to $0.1 \mathrm{M} \mathrm{KOH}$ led to a significant decrease in the $\mathrm{H}$ adsorption/desorption area $[0.05-0.45$ 


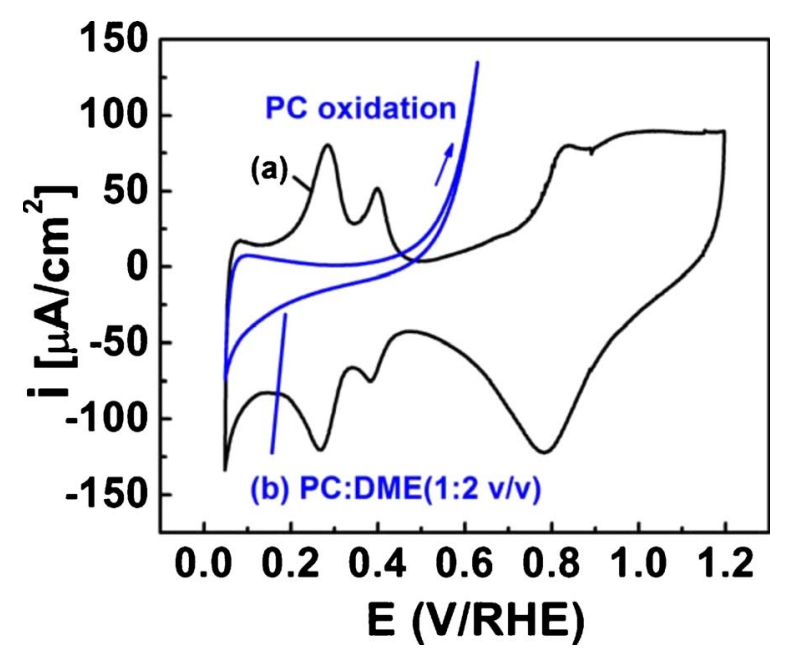

Figure 9. (Color online) Ar-saturated CVs at $50 \mathrm{mV} / \mathrm{s}(0 \mathrm{rpm})$ on polycrystalline $\mathrm{Pt}$ electrode in (a) $0.1 \mathrm{M} \mathrm{KOH}$ and (b) $61 \mathrm{mM} \mathrm{PC}$ $+100 \mathrm{mM}$ DME $(\mathrm{PC}: \mathrm{DME}=1: 2 \mathrm{v} / \mathrm{v})$ in $0.1 \mathrm{M} \mathrm{KOH}$

V vs reference hydrogen electrode (RHE)] indicating strong adsorption and to large oxidation currents above $0.5 \mathrm{~V}$ vs RHE.

Lastly, the ORR activity and the nature of ORR products on $\mathrm{Au}$ in aqueous electrolytes fall between that of $\mathrm{GC}$ and $\mathrm{Pt}$ : $(i)$ Its $\mathrm{pH}$ dependence is evident but less pronounced than on GC (see Fig. 7) and (ii) both $\mathrm{H}_{2} \mathrm{O}_{2}$ and $\mathrm{H}_{2} \mathrm{O}$ are produced at varying fractions, depending on the electrode potential in alkaline ${ }^{49}$ and acidic aqueous electrolytes. ${ }^{50}$ Changing to aprotic electrolytes with Li ions, the ORR overpotential is decreased significantly (Fig. 7) by the same potential difference between alkaline and organic electrolytes as that observed for GC, which suggests that the physical origin discussed for GC above may contribute to the difference. Overall, Au gives the highest $\mathrm{ORR}$ activity in $\mathrm{Li}^{+}$-containing aprotic electrolyte relative to carbon and $\mathrm{Pt}$ in both the RDE and $\mathrm{Li}-\mathrm{O}_{2}$ cell testing.

The various hypothesized reaction pathways above are summarized in Fig. 10, with the first step being the initial one-electron reduction of oxygen to a weakly adsorbed superoxide radical, as was proposed in previous studies. ${ }^{38,51,52}$ This is followed either by the dissolution of the superoxide radical solvated by large cations, ${ }^{27}$ $\mathrm{PC},{ }^{26}$ or lithium ions ${ }^{30}$ or by the formation of surface adsorbed $\mathrm{LiO}_{2}$ (for very low ratios of electrolyte volume to electrode surface area, as in a Li-air cell, solvated superoxide radicals likely readsorb and react). On catalysts with relatively strong oxygen adsorption strength (e.g., $\mathrm{Pt}$ ), adsorbed $\mathrm{LiO}_{2}$ is likely to get reduced all the way to $\mathrm{Li}_{2} \mathrm{O}$ (solid arrows in Fig. 10), while $\mathrm{LiO}_{2}$ reduction on catalysts with relatively weak oxygen adsorption strength (e.g., Au and GC) is likely to proceed only to $\mathrm{Li}_{2} \mathrm{O}_{2}$ (dot-dashed arrows in Fig. 10). Ex situ and in situ characterization of ORR products on different catalyst surfaces are needed to verify the proposed mechanisms, which will be reported in future studies.

\section{Conclusions}

RDE measurements in this study reveal the intrinsic ORR activity of GC, polycrystalline Au, and polycrystalline Pt surfaces in a $\mathrm{Li}^{+}$-containing aprotic electrolyte. The ORR activity trend ranks in the descending order of $\mathrm{Au} \gg \mathrm{GC}>\mathrm{Pt}$. The higher ORR activity of $\mathrm{Au}$ relative to carbon based on RDE experiments is consistent with the higher discharge voltages observed in $\mathrm{Li} / \mathrm{O}_{2}$ single cells, where discharge voltages between carbon alone and carbon mixed with $\mathrm{Au}$ nanoparticles (40 wt \% Au/carbon) differ by $\sim 100 \mathrm{mV}$ over the entire discharge. The ORR activity of GC is sufficiently high to dominate all the discharge voltages reported previously for composite air electrodes of different catalysts having carbon greater than 60 wt $\%$ as an additive. We provide some mechanistic insights to explain the observed ORR activity trend by comparing and discussing the ORR mechanisms on GC, Au, and Pt in the aprotic electrolytes with lithium ions with those without metal ions nor protons, where it is hypothesized that the competition between the solvation energy of oxygen molecules and adsorption strength of $\mathrm{O}_{2}$ on the catalyst surface can greatly influence the reaction pathway. The proposed reaction mechanisms and reaction intermediates of ORR in aprotic electrolytes with lithium ions are supported by discussing the ORR activities of these three surfaces in aqueous electrolytes and examining how they change as a function of $\mathrm{pH}$.

\section{Acknowledgment}

This work was supported in part by the MRSEC Program of the National Science Foundation under award no. DMR-0819762 and the Assistant Secretary for Energy Efficiency and Renewable Energy, Office of FreedomCAR and Vehicle Technologies of the U.S. Department of Energy under contract no. DE-AC03-76SF00098 with the Lawrence Berkeley National Laboratory and an MIT fellowship from the Martin Family Society of Fellows for Sustainability. The authors thank J. Kim and W. C. Sheng for providing the ORR data on Au (in alkaline) and on Pt (in alkaline and acid).

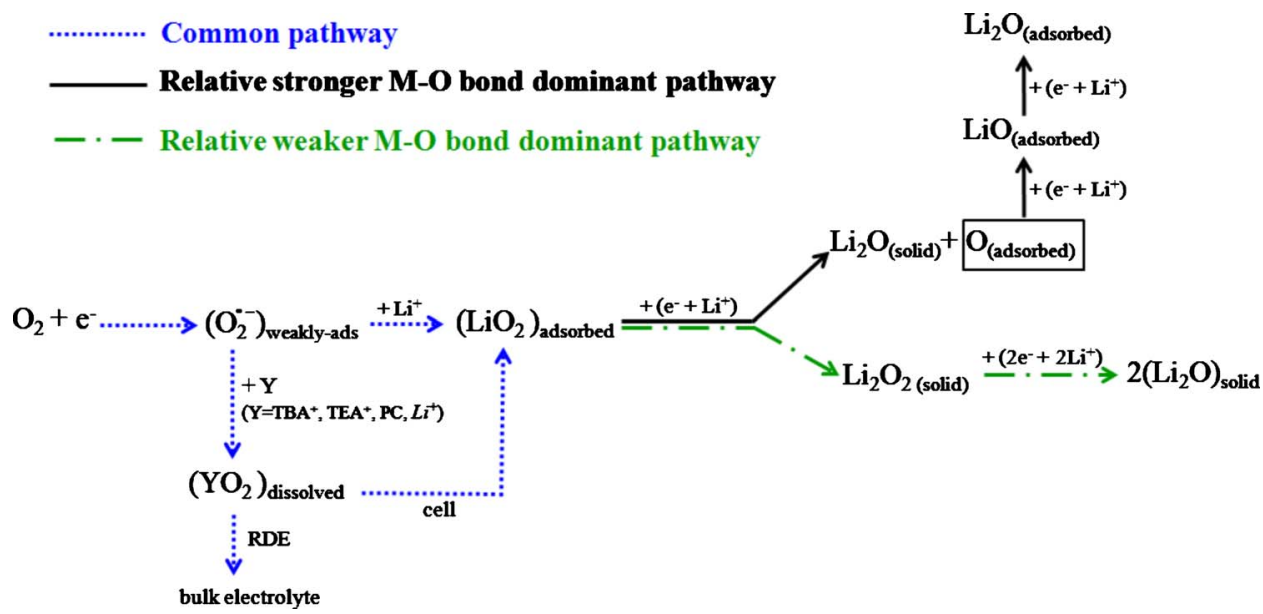

Figure 10. (Color online) Proposed ORR mechanism for $\mathrm{Li}^{+}$-containing aprotic solvents. 
Massachusetts Institute of Technology assisted in meeting the publication costs of this article.

\section{References}

1. T. Horiba, T. Maeshima, T. Matsumura, M. Koseki, J. Arai, and Y. Muranaka, J. Power Sources, 146, 107 (2005).

2. K. Snyder, DOE Merit Review: United States Advanced Battery Consortium, http://www1.eere.energy.gov/vehiclesandfuels/pdfs/merit_review_2009/ energy_storage/es_03_snyder.pdf, last accessed November 2009.

3. A. S. Aricò, P. Bruce, B. Scrosati, J.-M. Tarascon, and W. van Schalkwijk, Nature Mater, 4, 366 (2005).

4. M. Armand and J. M. Tarascon, Nature (London), 451, 652 (2008).

5. K. M. Abraham and Z. Jiang, J. Electrochem. Soc., 143, 1 (1996).

6. S. D. Beattie, D. M. Manolescu, and S. L. Blair, J. Electrochem. Soc., 156, A44 (2009).

7. K. M. Abraham, ECS Trans., 3(42), 67 (2008).

8. M. W. Chase, Jr., J. Phys. Chem. Ref. Data, Monograph 9, 1510 (1998).

9. J. S. Hummelshøj, J. Blomqvist, S. Datta, T. Vegge, J. Rossmeisl, K. S. Thygesen, A. C. Luntz, K. W. Jacobsen, and J. K. Nørskov, J. Chem. Phys., 132, 071101 (2010).

10. A. Débart, A. J. Paterson, J. Bao, and P. G. Bruce, Angew. Chem., Int. Ed., 47, 4521 (2008).

11. J. Read, J. Electrochem. Soc., 149, A1190 (2002).

12. T. Kuboki, T. Okuyama, T. Ohsaki, and N. Takami, J. Power Sources, 146, 766 (2005).

13. X.-H. Yang, P. He, and Y.-Y. Xia, Electrochem. Commun., 11, 1127 (2009)

14. H. Cheng and K. Scott, J. Power Sources, 195, 1370 (2010).

15. A. Débart, J. Bao, G. Armstrong, and P. G. Bruce, J. Power Sources, 174, 1177 (2007).

16. Y.-C. Lu, Z. C. Xu, H. A. Gasteiger, S. Chen, K. Hamad-Schifferli, and Y. ShaoHorn, J. Am. Chem. Soc., In press. [DOI: 10.1021/ja1036572]

17. T. Ogasawara, A. Debart, M. Holzapfel, P. Novak, and P. G. Bruce, J. Am. Chem. Soc., 128, 1390 (2006)

18. Y.-C. Lu, H. A. Gasteiger, M. C. Parent, V. Chiloyan, and Y. Shao-Horn, Electrochem. Solid-State Lett., 13, A69 (2010)

19. S. S. Sandhu, J. P. Fellner, and G. W. Brutchen, J. Power Sources, 164, 365 (2007).

20. H. A. Gasteiger, S. S. Kocha, B. Sompalli, and F. T. Wagner, Appl. Catal., B, 56, 9 (2005).

21. J. Read, K. Mutolo, M. Ervin, W. Behl, J. Wolfenstine, A. Driedger, and D. Foster, J. Electrochem. Soc., 150, A1351 (2003).

22. S. S. Zhang, D. Foster, and J. Read, J. Power Sources, 195, 1235 (2010).

23. W. Gu, D. R. Baker, Y. Liu, and H. A. Gasteiger, in Handbook of Fuel Cells Fundamentals, Technology and Applications, W. Vielstich, H. A. Gasteiger, and H. Yokokawa, Editors, p. 631, John Wiley \& Sons, Chichester (2009).

24. T. Okada, in Handbook of Fuel Cells - Fundamentals, Technology and Applications, W. Vielstich, H. A. Gasteiger, and H. Yokokawa, Editors, p. 627, John Wiley
\& Sons, Chichester (2003).

25. U. A. Paulus, T. J. Schmidt, H. A. Gasteiger, and R. J. Behm, J. Electroanal. Chem., 495, 134 (2001).

26. D. Aurbach, M. L. Daroux, P. Faguy, and E. Yeager, J. Electroanal. Chem. Interfacial Electrochem., 297, 225 (1991).

27. D. T. Sawyer, G. Chiericato, C. T. Angelis, E. J. Nanni, and T. Tsuchiya, Anal. Chem., 54, 1720 (1982).

28. B. Xie, H. S. Lee, H. Li, X. Q. Yang, J. McBreen, and L. Q. Chen, Electrochem. Commun., 10, 1195 (2008)

29. R. Rich, Hydrogen and the Alkali Metals Inorganic Reactions in Water, p. 25, Springer, Berlin Heidelberg (2008).

30. C. O. Laoire, S. Mukerjee, K. M. Abraham, E. J. Plichta, and M. A. Hendrickson, J. Phys. Chem. C, 113, 20127 (2009).

31. L. Andrews, J. Chem. Phys., 50, 4288 (1969).

32. L. Andrews and R. R. Smardzew, J. Chem. Phys., 58, 2258 (1973).

33. D. T. Sawyer and J. L. Roberts, Jr., J. Electroanal. Chem., 12, 90 (1966).

34. K. C. Neyerlin, W. Gu, J. Jorne, and H. A. Gasteiger, J. Electrochem. Soc., 153, A1955 (2006).

35. D. C. Sorescu, K. D. Jordan, and P. Avouris, J. Phys. Chem. B, 105, 11227 (2001).

36. B. Hammer and J. K. Norskov, Adv. Catal., 45, 71 (2000).

37. N. M. Markovic and P. N. Ross, Surf. Sci. Rep., 45, 117 (2002).

38. B. B. Blizanac, C. A. Lucas, M. E. Gallagher, M. Arenz, P. N. Ross, and N. M. Markovic, J. Phys. Chem. B, 108, 625 (2004).

39. G. Jürmann, D. J. Schiffrin, and K. Tammeveski, Electrochim. Acta, 53, 390 (2007).

40. T. J. Schmidt, V. Stamenkovic, M. Arenz, N. M. Markovic, and P. N. Ross, Electrochim. Acta, 47, 3765 (2002).

41. F. H. B. Lima, J. Zhang, M. H. Shao, K. Sasaki, M. B. Vukmirovic, E. A. Ticianelli, and R. R. Adzic, J. Phys. Chem. C, 111, 404 (2007).

42. E. L. Thompson, J. Jorne, W. B. Gu, and H. A. Gasteiger, J. Electrochem. Soc., 155, B625 (2008).

43. D. T. Sawyer, Oxygen Chemistry, Oxford University Press, New York (1991).

44. D. L. Maricle and W. G. Hodgson, Anal. Chem., 37, 1562 (1965).

45. J. K. Nørskov, T. Bligaard, J. Rossmeisl, and C. H. Christensen, Nat. Chem., 1, 37 (2009).

46. N. Markovic, H. Gasteiger, and P. N. Ross, J. Electrochem. Soc., 144, 1591 (1997).

47. K. J. J. Mayrhofer, V. Juhart, K. Hartl, M. Hanzlik, and M. Arenz, Angew. Chem., Int. Ed., 48, 3529 (2009).

48. K. J. J. Mayrhofer, D. Strmcnik, B. B. Blizanac, V. Stamenkovic, M. Arenz, and N. M. Markovic, Electrochim. Acta, 53, 3181 (2008).

49. S. Strbac, N. A. Anastasijević, and R. R. Adzić, J. Electroanal. Chem. Interfacial Electrochem., 323, 179 (1992).

50. R. R. Adžić, S. Strbac, and N. Anastasijevic, Mater. Chem. Phys., 22, 349 (1989).

51. M. H. Shao, P. Liu, and R. R. Adzic, J. Am. Chem. Soc., 128, 7408 (2006).

52. R. W. Zurilla, R. K. Sen, and E. Yeager, J. Electrochem. Soc., 125, 1103 (1978). 